\title{
Impacts of Silver Nanoparticles on Plants: A Focus on the Phytotoxicity and Underlying Mechanism
}

\author{
An Yan (1) and Zhong Chen * (1) \\ Natural Sciences and Sciences Education, National Institute of Education, Nanyang Technological University, \\ Singapore 637616, Singapore; an.yan@nie.edu.sg \\ * Correspondence: zhong.chen@nie.edu.sg; Tel.: +65-67903822
}

Received: 31 January 2019; Accepted: 21 February 2019; Published: 26 February 2019

\begin{abstract}
Nanotechnology was well developed during past decades and implemented in a broad range of industrial applications, which led to an inevitable release of nanomaterials into the environment and ecosystem. Silver nanoparticles (AgNPs) are one of the most commonly used nanomaterials in various fields, especially in the agricultural sector. Plants are the basic component of the ecosystem and the most important source of food for mankind; therefore, understanding the impacts of AgNPs on plant growth and development is crucial for the evaluation of potential environmental risks on food safety and human health imposed by AgNPs. The present review summarizes uptake, translocation, and accumulation of AgNPs in plants, and exemplifies the phytotoxicity of AgNPs on plants at morphological, physiological, cellular, and molecular levels. It also focuses on the current understanding of phytotoxicity mechanisms via which AgNPs exert their toxicity on plants. In addition, the tolerance mechanisms underlying survival strategy that plants adopt to cope with adverse effects of AgNPs are discussed.
\end{abstract}

Keywords: plants; AgNPs; phytotoxicity; uptake; reactive oxygen species (ROS)

\section{Introduction}

Due to their small size (between 1 and $100 \mathrm{~nm}$ ) and unique chemical and physical characteristics, engineered nanomaterials (ENMs) were developed and expanded for application in many industrial sectors and daily life. Among various types of ENMs, silver nanoparticles (AgNPs) are the most commonly applied nanomaterial. It is reported that nearly $25 \%$ of all nanotechnology consumer products involve AgNPs [1]. Because of their well-known antibacterial and antifungal properties, they can be used in household products, food packaging, textiles, medical devices, antiseptics in healthcare delivery, and personal healthcare [2-6]. AgNPs can also be used in electronic devices and wastewater treatment because of their good electrical conductivity and photochemical properties $[6,7]$.

In the agriculture sector, AgNPs were developed as plant-growth stimulators [8,9], fungicides to prevent fungal diseases [10], or agents to enhance fruit ripening [11,12]. The growing consumption of AgNPs inevitably increases the chance of release into the environment during AgNP synthesis and incorporation into products, as well as handling and recycling or disposal of these products [13-15]. AgNPs are expected to flow into environment as surface waters (e.g., lakes, streams, and rivers) [16], and the main pathway is through biosolids from wastewater treatment $[17,18]$. Indeed, AgNPs are detected widely in water and soil; they accumulate in the soil or water reservoirs in large quantities [19-21]. An analysis of the wastewater from a sewage treatment plant indicated existence of AgNPs with a size of $9.3 \mathrm{~nm}$ and a concentration of $1900 \mathrm{ng} / \mathrm{L}$ [22]. Moreover, the concentrations of AgNPs in surface water and sewage treatment are increasing significantly [21,23-25]. In agriculture, AgNP-contaminated water may permeate into fields through fertilization and irrigation [26]. The released AgNPs have the ability to permeate different media and eventually enter the plant 
rhizosphere $[27,28]$. Therefore, the AgNPs are inevitably taken up by crops and easily enter into the food chain [29], not only posing impacts on food production and food quality, but also posing a risk to human health [30-33].

Silver is the second most toxic metal to aquatic organisms after mercury [34]. Actually, AgNPs can leach silver ions $\left(\mathrm{Ag}^{+}\right)$, which are persistent, bioaccumulative, and highly toxic to organisms [35]. Therefore, the release of AgNPs into ecosystems raises great concerns about their safety and environmental toxicity. As plants are a vital part of ecosystem and the primary trophic level in ecosystems, representing the base of the food chain [36,37], a good understanding of the impacts of AgNPs on plants is of paramount importance for assessing their toxicity [38]. Hence, the present review describes the uptake and translocation of AgNPs, and gives a detailed summarization of the impacts of AgNPs on plants. The phytotoxicity mechanisms via which AgNPs cause impacts on plants and the tolerance mechanisms through which plants alleviate the detrimental effects of AgNPs are discussed for a better understanding of interactions between plants and AgNPs.

\section{Uptake and Translocation of AgNPs in Plants}

In plants, AgNPs are transported via the intercellular spaces (short-distance transport) and via vascular tissue (long-distance transport) [29,39-41]. After exposure to plants, NPs penetrate cell walls and plasma membranes of epidermal layers in roots, followed by a series of events to enter plant vascular tissues (xylem), and move to the stele. Xylem is the most important vehicle in the distribution and translocation of NPs [42]. Through xylem, AgNPs can be taken up and translocated to leaves. In Arabidopsis thaliana, AgNPs can be taken up by the roots and transported to the shoots [29]. Geisler-Lee et al. found that AgNPs was taken up and progressively accumulated in the root tips, from border cells to root cap, epidermis, columella, and initials of the root meristem [39]. A further study indicated that AgNPs attached to the surface of primary roots in Arabidopsis and then entered root tips at an early stage after exposure. After 14 days, AgNPs gradually moved into roots and entered lateral root primordia and root hairs. After multiple lateral roots were developed, AgNPs were present in vascular tissue and throughout the whole plant from root to shoot [40].

The cell wall of the root cells is the main site through which AgNPs enter in plant cells [43]. In order to enter into the plant, AgNPs need to penetrate the cell wall and plasma membranes of epidermal layer of roots. The cell wall is a porous network of polysaccharide fiber matrices and, thus, acts as natural sieve [44,45]. The small-sized AgNPs can pass through the pores, whereas larger AgNPs are unable to enter into plant cells and are thereby sieved out [43].

Interestingly, AgNPs can induce the formation of new and large-sized pores, which permits the internalization of large AgNPs through the cell wall [44]. AgNPs can also be transported within the plant cell through the plasmodesmata process $[29,46,47]$. Plasmodesmata are pores of $50-60 \mathrm{~nm}$ in diameter and connect adjacent neighboring plant cells. In Arabidopsis, AgNPs are found to aggregate in plasmodesmata and in the cell wall [39], suggesting that there may be blockage of intercellular communication, which may be caused by the mechanical presence of AgNPs at these sites and may affect nutrient intercellular transport [40].

In addition to the root pathway, AgNPs can also be taken up through plant leaves. Geisler-Lee et al. found that if cotyledons of the Arabidopsis seedlings were immersed in AgNP-containing medium, AgNPs could be taken up and accumulated in stomatal guard cells [40]. Larue et al. found that AgNPs were effectively trapped on lettuce leaves by the cuticle after foliar exposure, and AgNPs could penetrate the leaf tissue through stomata [48]. In addition, Li et al. compared the uptake of AgNPs in soybean and rice following root versus foliar exposure, and found that foliar exposure resulted in 17-200 times more Ag bioaccumulation than root exposure [49].

Once the AgNPs enter into vascular tissues of crops, they can be taken up and transported to the leaves or other organs through long-distance transport $[27,29,40]$. Therefore, it is possible that the fruits, seeds, and other edible parts of plants may also be subjected to contamination by AgNPs through translocation. 


\section{Phytotoxicity of AgNPs}

\subsection{Phytotoxicity at the Morphological Level}

After exposure to AgNPs, significant changes in the morphology of plants were observed. Growth potential, seed germination, biomass, and leaf surface area are the commonly used parameters for assessing the phytotoxicity of AgNPs in plants [27,42,43]. It was demonstrated that AgNP exposure could inhibit seed germination and root growth, and reduce biomass and leaf area. Jiang et al. found that AgNPs significantly decreased plant biomass, inhibited shoot growth, and resulted in root abscission in Spirodela polyrrhiza [50]. Kaveh et al. showed that exposure to higher concentrations (from 5 to $20 \mathrm{mg} / \mathrm{L}$ ) of AgNPs resulted in reduction of the biomass in Arabidopsis [51]. Dimkpa et al. found that AgNPs reduced the length of shoots and roots of wheat in a dose-dependent manner in wheat [52]. Similarly, Nair and Chung showed that AgNPs significantly reduced root elongation, and shoot and root fresh weights in rice [53]. Stampoulis et al. demonstrated that AgNPs ( $>100 \mathrm{mg} / \mathrm{L})$ inhibited seed germination and reduced biomass in zucchini (Cucurbita pepo) [54]. Similar results regarding the toxicity on seed germination, biomass accumulation, and root and shoot growth by AgNPs were reported in other studies involving various plant species, including Arabidopsis [55], Brassica nigra [56], Lemna [57], Phaseolus radiatus and Sorghum bicolor [58], Lolium multiflorum [59], rice [60], wheat [61], Lupinus termis L. [62], and so on. A summary of compiled descriptions of the effects of AgNPs in plants is shown in Table 1.

Table 1. Summary of studies on phytotoxicity of silver nanoparticles (AgNPs) in plants.

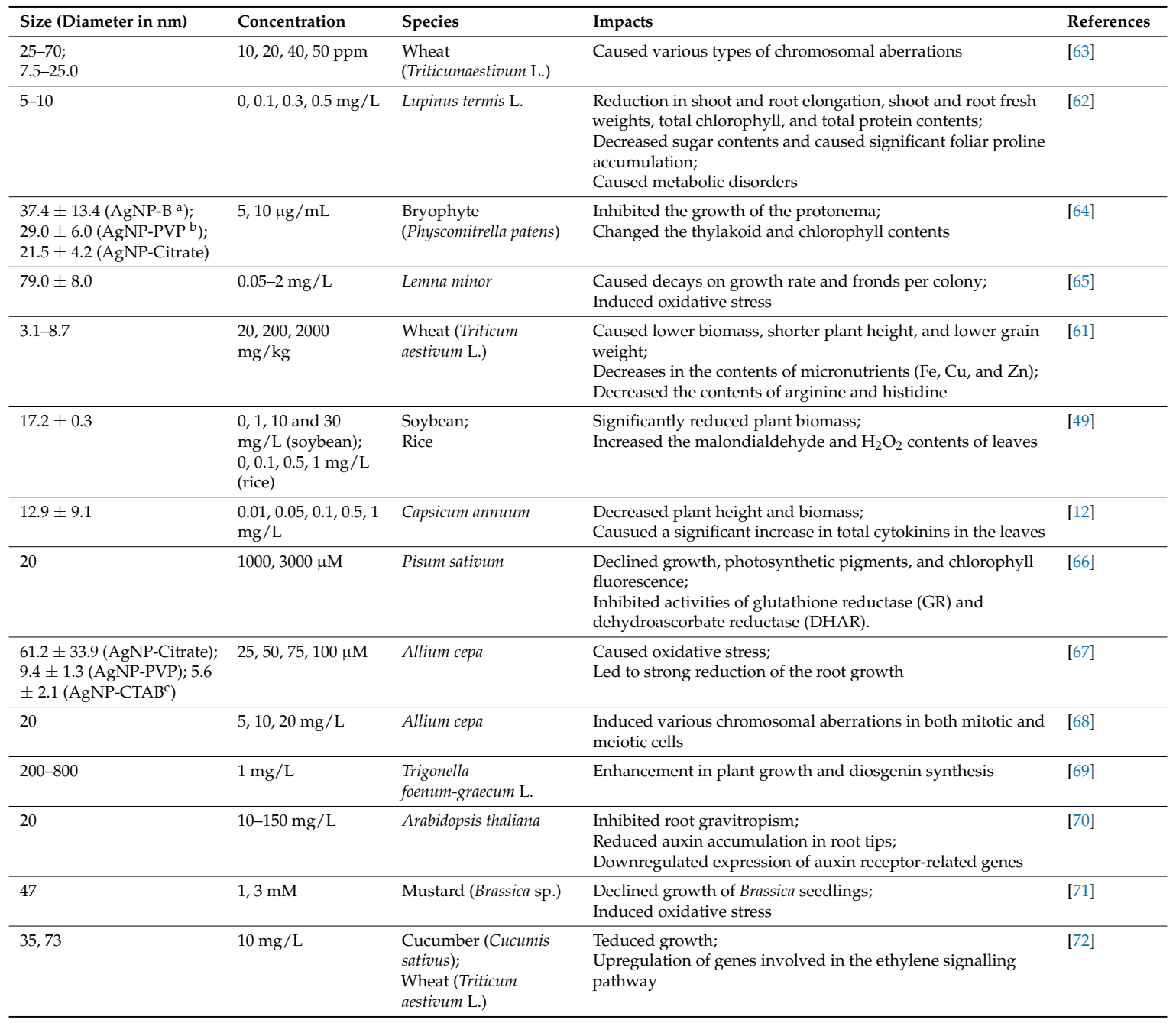


Table 1. Cont

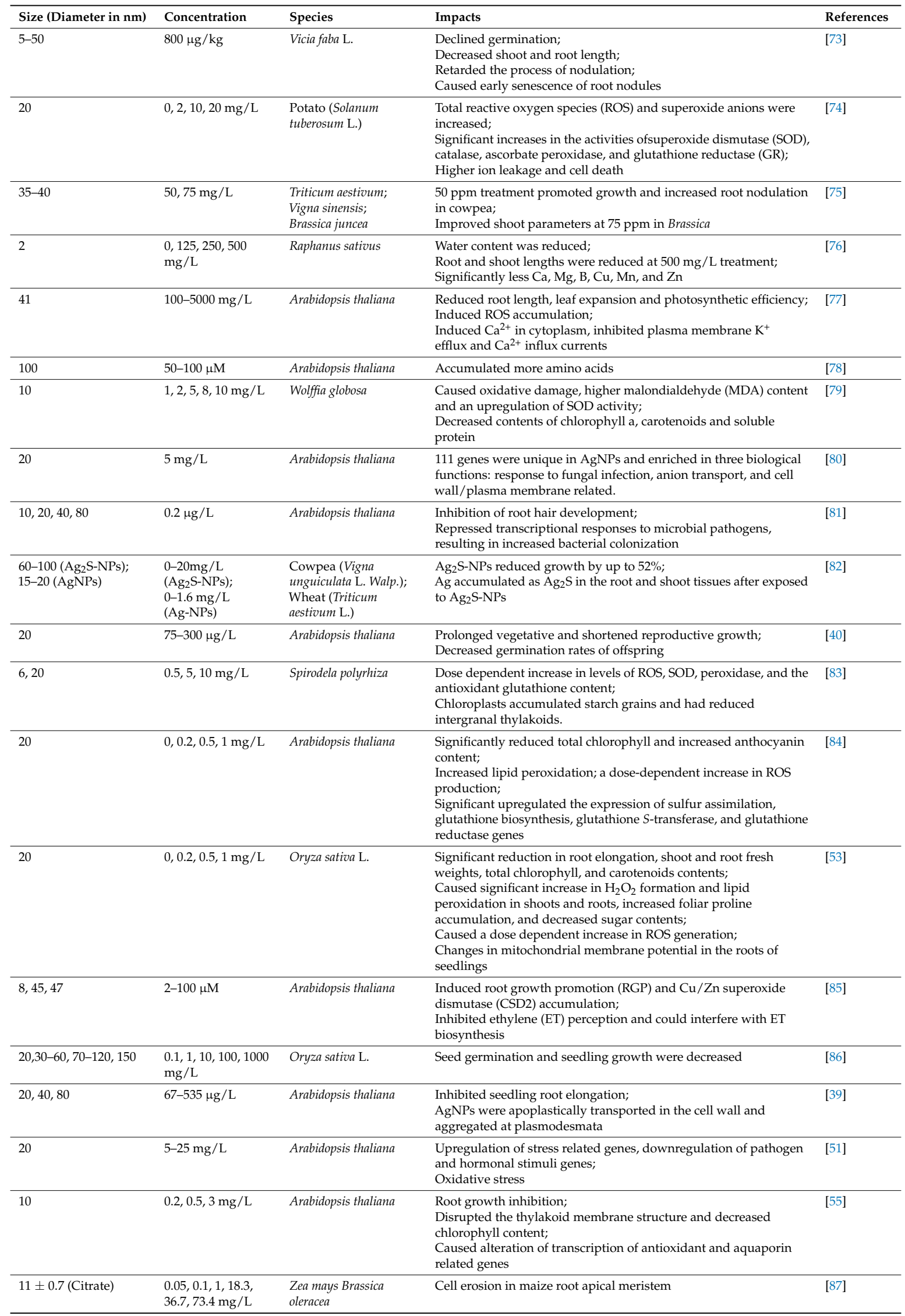


Table 1. Cont.

\begin{tabular}{|c|c|c|c|c|}
\hline Size (Diameter in $\mathrm{nm}$ ) & Concentration & Species & Impacts & References \\
\hline 18.34 & $0.30-60 \mathrm{mg} / \mathrm{L}$ & Oryza sativa $\mathrm{L}$. & $\begin{array}{l}\text { Damage the cell morphology and its structural features; } \\
\text { Total soluble carbohydrates significantly declined; } \\
\text { Caused production of the ROS and local root tissue death }\end{array}$ & [88] \\
\hline 10 & $\begin{array}{l}0.5,1.5,2.5,3.5,5 \\
\mathrm{mg} / \mathrm{kg}\end{array}$ & Triticum aestivum & $\begin{array}{l}\text { Teduced the length of shoots and roots; } \\
\text { Caused oxidative stress in roots; } \\
\text { Induced expression of a metallothionein gene involved in } \\
\text { detoxification }\end{array}$ & [52] \\
\hline $10-15$ & $0,100,1000 \mathrm{mg} / \mathrm{L}$ & $\begin{array}{l}\text { Tomatoes (Lycopersicon } \\
\text { esculentum) }\end{array}$ & $\begin{array}{l}\text { Significant decreases in root growth; } \\
\text { Decreased chlorophyll contents and Higher SOD activity; } \\
\text { Less fruit productivity, }\end{array}$ & [89] \\
\hline $5,10,25$ & $0.01-100 \mathrm{mg} / \mathrm{L}$ & $\begin{array}{l}\text { Arabidopsis thaliana; } \\
\text { poplars }\end{array}$ & $\begin{array}{l}\text { Stimulatory effect on root elongation, fresh weight, and } \\
\text { evapotranspiration at sublethal concentrations; } \\
\text { Toxicity increased with decreasing AgNPs size }\end{array}$ & [90] \\
\hline $\begin{array}{l}20(\text { AgNP-PVP) } 6 \\
\left(\text { AgNP-GA }^{\mathrm{d}}\right)\end{array}$ & $1,10,40 \mathrm{mg} / \mathrm{L}$ & $\begin{array}{l}\text { Eleven species of } \\
\text { wetland plants }\end{array}$ & $\begin{array}{l}40 \mathrm{mg} / \mathrm{L} \text { AgNPs-GA exposure significantly reduced the } \\
\text { germination rate of three species and enhanced the germination } \\
\text { rate of one species. }\end{array}$ & [91] \\
\hline$<100$ & $250,750 \mathrm{mg} / \mathrm{L}$ & Cucurbita pepo & Reduction in plant biomass and transpiration & [92] \\
\hline $5-25$ & $\begin{array}{l}0,5,10,20,40 \\
\mathrm{mg} / \mathrm{L}\end{array}$ & $\begin{array}{l}\text { Phaseolus radiates; } \\
\text { Sorghum bicolor }\end{array}$ & Inhibition of plant growth & [58] \\
\hline$<100$ & $0,100,500 \mathrm{mg} / \mathrm{L}$ & Cucurbita pepo & Decreased rate of transpiration & [93] \\
\hline 60 & $\begin{array}{l}12.5,25,50,100 \\
\mathrm{mg} / \mathrm{L}\end{array}$ & Vicia faba & $\begin{array}{l}\text { Increased the number of chromosomal aberrations and micronuclei, } \\
\text { and decreased the mitotic index }\end{array}$ & [94] \\
\hline $190-1100$ & $\begin{array}{l}0,25,50,100,200 \text { or } \\
400 \mathrm{mg} / \mathrm{L}\end{array}$ & Brassica juncea & $\begin{array}{l}\text { Increase in root length and increase in vigor index; } \\
\text { Improved photosynthetic quantum efficiency and higher } \\
\text { chlorophyll contents; } \\
\text { Induced the activities of antioxidant enzymes, resulting in reduced } \\
\text { reactive oxygen species levels }\end{array}$ & [95] \\
\hline 20,100 & $5 \mu \mathrm{g} / \mathrm{L}$ & Lemna minor L. & Inhibition of plant growth & [57] \\
\hline 25 & $50,500,1000 \mathrm{mg} / \mathrm{L}$ & Oryza sativa & Broken the cell wall and damaged the vacuoles of root cells & [96] \\
\hline $24-55$ & $0-80 \mathrm{mg} / \mathrm{L}$ & Allium cepa & Induced cell death and DNA damage through generation of ROS & [97] \\
\hline$<100$ & $100 \mathrm{ppm}$ & Allium cepa & $\begin{array}{l}\text { Disturbed mitosis, reduction in mitotic index, declined metaphase, } \\
\text { sticky chromosome, disintegration and breakdown of cell wall }\end{array}$ & [98] \\
\hline 20 & $100 \mathrm{mg} / \mathrm{L}$ & Green asparagus & Higher ascorbic acid and total chlorophyll contents & [99] \\
\hline
\end{tabular}

\subsection{Phytotoxicity at Physiological Level}

Phytotoxicity of AgNPs to plants at the physiological level is predicted by reduction of chlorophyll and nutrient uptake, decline of transpiration rate, and alteration of hormone. AgNPs can disrupt the synthesis of chlorophyll in leaves and, thus, affect the photosynthetic system of the plants [43]. Qian et al. showed that AgNPs could accumulate in Arabidopsis leaves, further disrupt the thylakoid membrane structure, and decrease chlorophyll content, leading to the inhibition of plant growth [55]. Nair and Chung reported that, after exposure to AgNPs for one week, total chlorophyll and carotenoids contents were decreased significantly in rice (Oryza sativa L.) seedlings [53]. Vishwakarma et al. found that AgNPs could accumulate in mustard (Brassica sp.) seedlings and caused severe inhibition in photosynthesis [71]. A recent study showed that AgNP exposure changed the thylakoid in Physcomitrella patens, and AgNPs decreased the chlorophyll $\mathrm{b}$ content and disturbed the balance of some essential elements in the leafy gametophytes [64]. In Lupinus termis L. seedlings, after exposure to AgNPs for ten days, the shoot and root elongation and fresh weights, total chlorophyll, and total protein contents were significantly reduced [62]. In Cucurbita pepo, the rate of transpiration was remarkably reduced after AgNP exposure [54,92,93].

In addition, AgNPs can affect the fluidity and permeability of the membrane and, consequently, influence water and nutrient uptake. Zuverza-Mena et al. demonstrated that AgNP exposure on radish (Raphanus sativus) sprout caused a decrease in water content in a dose-dependent manner; the nutrient content $(\mathrm{Ca}, \mathrm{Mg}, \mathrm{B}, \mathrm{Cu}, \mathrm{Mn}$, and $\mathrm{Zn}$ ) was also significantly reduced, suggesting that AgNPs may affect plant growth by changing water and nutrient content [76].

It was reported that AgNPs also affect plant hormones. Sun et al. found that the root gravitropism of Arabidopsis seedling was inhibited by exposure to AgNPs in a dose-dependent manner. Further 
analysis indicated that AgNPs reduced auxin accumulation, while gene expression analysis suggested that auxin receptor-related genes were downregulated upon AgNP exposure [70]. Vinković et al. conducted hormonal analysis using ultra-high-performance liquid chromatography electrospray, and found that AgNP accumulation in pepper tissue resulted in a significant increase in total cytokinin levels, suggesting the importance of cytokinin in the plant's response to AgNPs stress [12]. Wang et al. found that $\mathrm{Ag}_{2} \mathrm{~S}-\mathrm{NPs}$ could reduce the growth of cucumber and wheat; expressions of six genes involved in ethylene signalling pathway were significantly upregulated in cucumber after exposure to $\mathrm{Ag}_{2} \mathrm{~S}-\mathrm{NPs}$, suggesting that $\mathrm{Ag}_{2} \mathrm{~S}-\mathrm{NPs}$ could affect plant growth through an interface with the ethylene signaling pathway [72].

\subsection{Cytotoxicity and Genotoxicity}

AgNPs can also cause toxicity at the cellular and molecular level in plants. Many studies showed that the inhibition of plant growth after AgNP exposure is accompanied with alteration of cell structure and cell division. Yin et al. found that Lolium multiflorum seedlings failed to develop root hair, and the cortical cells were highly vacuolated and collapsed, while the epidermis and root cap were also damaged after exposure to $40 \mathrm{mg} / \mathrm{L}$ AgNPs [59]. Pokhrel and Dubey observed that AgNPs could reduce the size of the vacuole and lead to the reduction of cell turgidity and cell size in maize (Zea mays L.) and cabbage (Brassica oleracea var. capitata L.) $[87,100]$. Similarly, Mazumdar found that after AgNPs enter the cell of Brassica campestris; vacuoles and cell wall integrity were damaged, and other organelles might also be affected [63,101]. Likewise, Mirzajani et al. found that AgNPs with a concentration of to $60 \mu \mathrm{g} / \mathrm{mL}$ could penetrate the cell wall, and damage the cell morphology and its structure in rice [88]. In addition, Kumari et al. reported that AgNP exposure in Allium cepa significantly decreased the mitotic index and impaired cell division, resulting in chromatin bridge, stickiness, disturbed metaphase, multiple chromosomal breaks, and cell disintegration [98]. Similarly, Patlolla et al. demonstrated that AgNP treatment significantly increased the chromosomal aberrations and micronuclei, and decreased the mitotic index (MI) in root tip cells of broad bean (Vicia faba L.), suggesting that cell cycle and mitosis in root tip cells was disrupted by AgNPs [94]. A recent study confirmed that the root tip cells of wheat could readily internalize the AgNPs. After AgNP internalization, the root tip cells exhibited various types of chromosomal aberrations, such as incorrect orientation at metaphase, chromosomal breakage, spindle dysfunction, fragmentation, unequal separation, and distributed and lagging chromosomes, which seriously interfered with cell function [63]. The uptake, translocation, and major phytotoxicity of AgNPs in plants are illustrated in Figure 1.

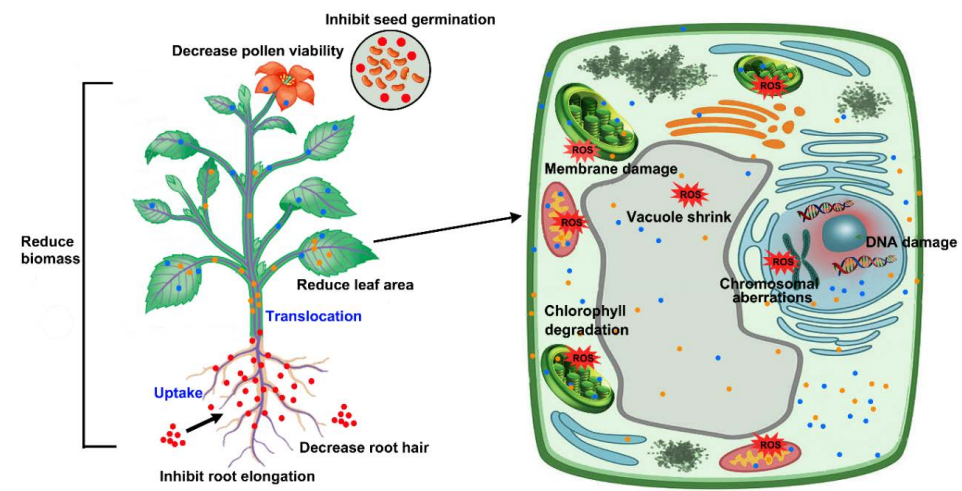

Figure 1. Schematic diagram representing uptake, translocation, and major phytotoxicity of silver nanoparticles (AgNPs) in plant (modified from Reference [102]). Generally, AgNPs are taken up by underground tissues (primary roots and lateral roots), then translocated to aboveground parts (stem, leaf, flower, etc.), where they can reduce biomass, decrease leaf area, affect pollen viability, and inhibit seed germination. At the cellular level, AgNPs enter into various organelles, leading to the production of excess reactive oxygen species (ROS), thereby causing cytotoxicity and genotoxicity, such as membrane damage, chlorophyll degradation, vacuole shrinkage, DNA damage, and chromosomal aberrations. 


\section{Toxicity Mechanisms}

\subsection{AgNP-Induced Oxidative Stress}

The main mechanism underlying the phytotoxicity of AgNPs is the production of excess reactive oxygen species (ROS) induced by AgNPs, resulting in oxidative stress in plant cells [100,103]. A number of studies demonstrated that ROS production is significantly elevated in plants after exposure to AgNPs. There are four types of ROS produced in plant cells, including singlet oxygen $\left({ }^{1} \mathrm{O}_{2}\right)$, superoxide $\left(\mathrm{O}_{2}{ }^{\bullet-}\right)$, hydrogen peroxide $\left(\mathrm{H}_{2} \mathrm{O}_{2}\right)$, and hydroxyl radical $\left(\mathrm{HO}^{\bullet}\right)$ [36,104]. Under normal environmental conditions, ROS are generated as byproducts of normal metabolic pathways in organelles such as chloroplasts, mitochondrion, and peroxisomes [36,105]. Under stressed conditions, however, excessive amounts of ROS are generated and cause severe oxidative damage to plant biomolecules through electron transfer [106]. The production of excess ROS induced by AgNP exposure can subsequently lead to oxidative stress, cause peroxidation of polyunsaturated fatty acids (known as lipid peroxidation), and damage the cell membrane permeability and alter cell structure, directly damaging protein and DNA, resulting in potential cell death and growth inhibition in plants (Figure 1) [36,100,107-109]. For example, Panda et al. reported that AgNP-P (phyto-synthesized from silver nitrate $\mathrm{AgNO}_{3}$ ) or AgNP-S (commercial AgNPs from Sigma-Aldrich) application in Allium cepa significantly increased the generation of superoxide $\left(\mathrm{O}_{2}{ }^{\bullet-}\right)$ and $\mathrm{H}_{2} \mathrm{O}_{2}$; they also induced cell death to different extents in a dose-dependent fashion, following an order of AgNP-S > AgNP-P at doses $\geq 20 \mathrm{mg} / \mathrm{L}$. Moreover, AgNP-P significantly decreased the mitotic index. Comet assay suggested that DNA damage was significantly enhanced after AgNP-P and AgNP-S treatments in a dose-dependent manner, whereby AgNP-S (threshold dose $\geq 10 \mathrm{mg} / \mathrm{L}$ ) is more genotoxic than AgNP-P (threshold dose $\geq 20 \mathrm{mg} / \mathrm{L}$ ) [97]. Qian et al. found that AgNPs could accumulate in Arabidopsis leaves and change the transcription of antioxidant and aquaporin genes, suggesting that AgNPs can change the balance between oxidant and antioxidant systems [55]. Similarly, Speranza et al. checked the in vitro toxicity of AgNPs to kiwifruit pollen, and found that changes in ROS generation paralleled the entire germination dynamics of kiwifruit pollen. The AgNP treatment delayed $\mathrm{H}_{2} \mathrm{O}_{2}$ production, whereas AgNPs dramatically induced ROS overproduction at the late stage during pollen germination, leading to decreases in pollen viability and performance [110]. Moreover, Torre-Roche et al. found that AgNP exposure with concentration at 500 and $2000 \mathrm{mg} / \mathrm{L}$ caused significant increases (54-75\%) in malondialdehyde (MDA) formation in soybean (Glycine max) [111]. MDA is a major peroxidation product under stress conditions and is indicative of the extent of lipid peroxidation [112]. Similarly, Nair and Chung reported that lipid peroxidation increased significantly after exposure to 0.2, 0.5, and $1 \mathrm{mg} / \mathrm{L}$ AgNPs in Arabidopsis [84]. In rice, Nair and Chung found that exposure to 0.5 and $1 \mathrm{mg} / \mathrm{L}$ AgNPs resulted in a significant increase in $\mathrm{H}_{2} \mathrm{O}_{2}$ formation and lipid peroxidation in shoots and roots; further analysis suggested that ROS production was promoted by AgNPs in a dose-dependent manner [53]. Thiruvengadam et al. reported the impact of AgNP exposure in turnip seedlings, and found that a higher concentration of AgNPs caused excessive generation of superoxide radicals and increased lipid peroxidation; $\mathrm{H}_{2} \mathrm{O}_{2}$ formation was also significantly increased after exposure to 5 and $10 \mathrm{mg} / \mathrm{L}$ AgNPs. Dichlorofluorescein (DCF) fluorescence indicated a sharp increase in ROS production in turnip seedling roots, suggesting the existence of oxidative stress in the roots after AgNP exposure. Further analysis by comet assay and terminal deoxynucleotidyl transferase-mediated dUTP nick end labeling (TUNEL) assay confirmed that DNA damage was significant, suggesting that AgNPs can induce cell death through apoptosis [113].

\subsection{Silver-Specific Toxicity}

It was shown that AgNPs can leach ionic silver $\left(\mathrm{Ag}^{+}\right)$into the surroundings through the oxidation of zero-valent $\mathrm{Ag}$ [114]. During AgNP uptake and translocation, $\mathrm{Ag}^{+}$is released from $\mathrm{AgNPs}_{\text {, resulting }}$ in oxidative stress through the generation of ROS and disturbing cell function, causing phytotoxicity by binding to cell components and modifying their activities [115-117]. For example, Speranza et al. analyzed the ion release kinetics of AgNPs in the pollen culture medium, and found that AgNPs 
rapidly dissolved into ions and reached a maximum of $11.8 \mathrm{wt} . \%$ ion release. The released $\mathrm{Ag}^{+}$caused a fivefold increase in $\mathrm{H}_{2} \mathrm{O}_{2}$ production over controls; moreover, the released $\mathrm{Ag}^{+}$damaged pollen membranes and inhibited germination to a greater extent than the AgNPs themselves, suggesting that $\mathrm{Ag}^{+}$may excert its impacts mostly through chemical or physicochemical interactions with nucleic acids to induce DNA damage [110]. A gene expression study by microarray in Arabidopsis compared gene expression profiles between AgNP and silver ion $\left(\mathrm{Ag}^{+}\right)$treatments and found a significant overlap between genes differentially expressed in the two treatments, suggesting a similarity between plants' responses to AgNPs and $\mathrm{Ag}^{+}$[51]. Actually, when AgNPs oxidize in water, they can make bonds with anions and transform into the characteristics of heavy metals, which is more hazardous [43,118]. It was demonstrated that the conversion of AgNPs to a complex of anion or heavy metal could cause toxic effects on various living organisms [25,119-121].

$\mathrm{Ag}^{+}$can also affect photosynthesis through competitive substitution of $\mathrm{Cu}^{+}$in plastocyanin (Pc). Pc is a soluble copper-binding protein found in the thylakoid lumen of the chloroplast. It functions as an electron carrier to transfer electrons from cytochrome $b_{6} / f$ to photosystem 1 (PS1) in the photosynthetic electron-transfer (ET) chain [122,123]. Pc contains a type 1 copper site, where the copper ion is surrounded by two histidine ligands (His87, His37) and a cysteine ligand (Cys84) [124]. $\mathrm{Ag}^{+}$can competitively replace $\mathrm{Cu}^{+}$and bind to $\mathrm{Pc}$, which results in disturbance or inactivation of the photosynthetic electron transport. Sujak found that Ag-substituted Pc occupied the active Pc electron transfer site of the cytochrome $f$, and caused a decrease in the turnover of the cytochrome complex [125]. Similarly, Jansson and Hansson demonstrated that $\mathrm{Ag}(\mathrm{I})$-substituted Pc competitively inhibited electron transfer between normal Cu-containing Pc and PS1 [126]. Since both AgNPs and dissolved silver can be toxic to plants, the phytotoxicity of AgNPs becomes complicated, as the plant is subjected to both silver-specific and nanoparticle-specific biological effects [51]. Therefore, it is difficult to say whether the phytotoxicity is caused by ionic sliver or by intrinsic properties of AgNPs in certain AgNP application scenarios.

\subsection{AgNP-Specific Toxicity}

Although the phytotoxicity of AgNPs was associated with the impact of dissolved $\mathrm{Ag}^{+}$on plants, the phytotoxicity effect could not be explained solely by the activity of the released $\mathrm{Ag}^{+}$ions. In some case, AgNPs can be even more toxic than free $\mathrm{Ag}^{+}$ions even at the same concentrations of $\mathrm{Ag}^{+}$[127]. In another study, AgNP exposure to Cucurbita pepo caused more reduction in biomass and transpiration when compared with bulk Ag [93]. These studies suggest that free $\mathrm{Ag}^{+}$ions contribute only partially to the phytotoxicity of AgNPs, while the intrinsic properties of AgNPs are critical for the phytotoxicity of AgNPs.

Indeed, the physical interactions between AgNPs and plant cell-transport pathways can influence the phytotoxicity of AgNPs [29]. Uptake of AgNPs into plant tissue may cause inhibition of apoplastic trafficking by clogging of pores and barriers in the cell wall or the nano-sized plasmodesmata, thereby effectively inhibit the apoplastic flow of water and nutrients $[43,128]$.

A number of studies suggested that the effect and phytotoxicity of AgNPs are closely associated with the nature of the interactions between plants and AgNPs, which are determined by the intrinsic properties of AgNPs [100,129]. These physical and chemical properties of AgNPs, including size, shape, exposure concentration, surface coating, Ag form, and aggregation state, greatly influence the effect of AgNPs on different aspects of plant morphology, physiology, and biochemistry [130].

Among these properties, the size of AgNPs is critical for the phytotoxicity of AgNPs [129]. The smaller-sized AgNPs have a larger surface area to mass ratio, which allows better interference with cell membrane function by directly reacting with the membrane. Meanwhile, a higher proportion of the atoms of the particle on the surface can affect the interfacial reactivity and the ability to pass through physiological barriers $[129,131]$. It was shown that smaller AgNPs could accumulate to higher levels in plants and be more toxic than their bulk particles. Geisler-Lee et al. checked the impact of AgNPs with different sizes (20, 40, and $80 \mathrm{~nm}$ ) on Arabidopsis, and found that smaller AgNPs accumulated more in 
seedlings than larger AgNPs $(20 \mathrm{~nm}>40 \mathrm{~nm}>80 \mathrm{~nm})$ at low concentrations. Moreover, smaller-sized AgNPs had a greater impact on root browning [39]. In another study, Wang et al. reported that smaller AgNPs ( 5 and $10 \mathrm{~nm}$ ) accumulated to higher levles in poplar tissues than the larger 25-nm AgNPs when applied within the particle subinhibitory concentration range; both Arabidopsis and poplar showed susceptibility to the toxic effects of AgNPs, and this susceptibility increased with decreasing AgNP size [90]. Various phytotoxicity studies using different sizes of AgNPs suggested that phytotoxicity is negatively correlated with the size of AgNPs, as AgNPs with smaller size are generally more toxic to the plants than larger AgNPs $[33,83,91,130]$. For example, Yin et al. showed that AgNP toxicity was influenced by AgNP surface area; smaller AgNPs $(6 \mathrm{~nm})$ more strongly affected plant growth than larger (25 nm) AgNPs when applied with similar concentrations in Lolium multiflorum [59]. Similarly, another study showed that 6-nm gum arabic coated silver nanoparticles (AgNP-GA) have stronger effects on germination and growth of wetland plants than 21-nm polyvinylpyrrolidone-coated silver nanoparticles (AgNP-PVP) [91]. Abdel-Azeem and Elsayed examined the effect of different sizes of AgNPs (20,50, and $65 \mathrm{~nm}$ ) on Vicia faba and found that the effect of AgNPs on the mitotic index and chromosomal aberrations was AgNP size-dependent, as smaller-sized AgNPs caused a lower mitotic index and root growth values, confirming that smaller AgNPs are more toxic to Vicia faba [132].

Although these studies demonstrated that smaller AgNPs cause more phytotoxicity than larger AgNPs, this correlation between AgNP size and phytotoxicity is not always true for every AgNP exposure scenario. For example, Thuesombat et al. examined the effects of different sized AgNPs $(20,30-60,70-120$, and $150 \mathrm{~nm})$ on seed germination and seedling growth in jasmine rice (Oryza sativa L. cv. KDML 105), and found that smaller AgNPs accumulated to higher levels than larger AgNPs, which is consistent with previous studies. However, both seed germination and seedling growth were decreased with increasing size; the 20-nm AgNPs treatment resulted in the less negative effects on seedling growth when compared to treatment with the larger AgNPs (150 nm), which is contrary to previous reports. Further analysis found that 20-nm AgNPs were trapped in the roots rather than transported to the leaves, thereby causing less phytotoxicity on seedling growth than 150-nm AgNPs [86].

Numerous studies on the phytotoxicity of AgNPs revealed that the phytotoxicity of AgNPs is positively correlated with the concentration of AgNPs during exposure. AgNPs can only cause negative effects on plants when applied with a concentration above a certain threshold. Mirzajani et al. showed that AgNPs were unable to change cell morphology or structure of rice root when present in low concentrations $(30 \mu \mathrm{g} / \mathrm{mL}$ ), whereas, with an increased concentration of $60 \mu \mathrm{g} / \mathrm{mL}$, AgNPs not only penetrated the cell wall, but also destroyed the cell morphology and the structural features. Moreover, $30 \mu \mathrm{g} / \mathrm{mL}$ AgNPs even accelerated root growth, while AgNPs at $60 \mu \mathrm{g} / \mathrm{mL}$ restricted root growth [88]. Oukarroum et al. reported that AgNP treatment induced intracellular ROS production in the aquatic plant Lemna gibba; the induced oxidative stress was positively correlated with the increasing concentration of AgNPs [133]. Similarly, Thuesombat et al. showed that seed germination and subsequent seedling growth were decreased with increased concentrations of AgNPs in jasmine rice [86]. Cvjetko et al. found that AgNPs induced oxidative stress and exhibited phytotoxicity only when applied in higher concentrations in Allium cepa roots [67].

Engineered AgNPs are typically stabilized against aggregation through surface coating, using organic or inorganic compounds to coat the surface of AgNPs to obtain electrostatic, steric, or electrostatic repulsive forces between particles [134]. Surface coating may change AgNP properties such as optical properties, dispersion, and shape $[65,135]$, thereby influencing the toxicity of AgNPs to plants. Cvjetko et al. compared the toxicity of three types of AgNPs with different surface coatings (citrate, polyvinylpyrrolidone (PVP), and cetyltrimethylammonium bromide (CTAB)) on Allium cepa roots, and found that plants treated with AgNP-CTAB had significantly higher Ag content than plants treated with AgNP-citrate and AgNP-PVP, leading to strong inhibition of root growth and oxidative damage. Among the treatments of three types of AgNPs, AgNP-CTAB caused the highest toxicity, whereas AgNP-citrate showed the weakest effects, as AgNP-citrate was much bigger in size and 
aggregated to larger particles. These observations suggest that the toxicity of AgNPs is correlated with the size and surface coating [67]. Similarly, Pereira et al. found that AgNP-PVP was more deleterious on the growth rate and fronds per colony than AgNP-citrate in Lemna minor, whereby AgNP-PVP reduced the growth rate 1.5-fold more than AgNP-citrate [65]. In another study, Liang et al. observed the responses of Physcomitrella patens to AgNPs with different surface coatings at the gametophyte stages, and found that AgNPs without surface coating caused the worst damage to the chlorophyll of protonemata, whereas AgNP-PVP and AgNP-citrate just displayed negligible influence, suggesting that surface coating alleviated the damage of AgNPs to the chlorophyll of protonemata. However, at the leafy gametophyte stage, exposure to AgNP-citrate led to the highest weight loss of leafy gametophytes, followed by AgNP-PVP and AgNPs without surface coating [64]. These observations suggest that the effects of AgNPs with different surface coatings on plants are complicated and are associated with the stability of AgNPs, as well as different plant systems.

In addition, the morphology of AgNPs also influences the effect of AgNPs on plants. Syu et al. studied the impacts of AgNPs with three different shapes (spherical, decahedral, and triangular) on Arabidopsis, and found that decahedral AgNPs induced the highest degree of root growth promotion but the lowest levels of $\mathrm{Cu} / \mathrm{Zn}$ superoxide dismutase (CSD2) accumulation. Triangular AgNPs also enhanced root growth, whereas spherical AgNPs exhibited no root growth promotion, but induced the highest levels of anthocyanin and CSD2 accumulation, suggesting that different morphologies of AgNPs exhibited different levels of effects on Arabidopsis [85]. A schematic diagram of AgNPs-specific toxicity is shown in Figure 2.

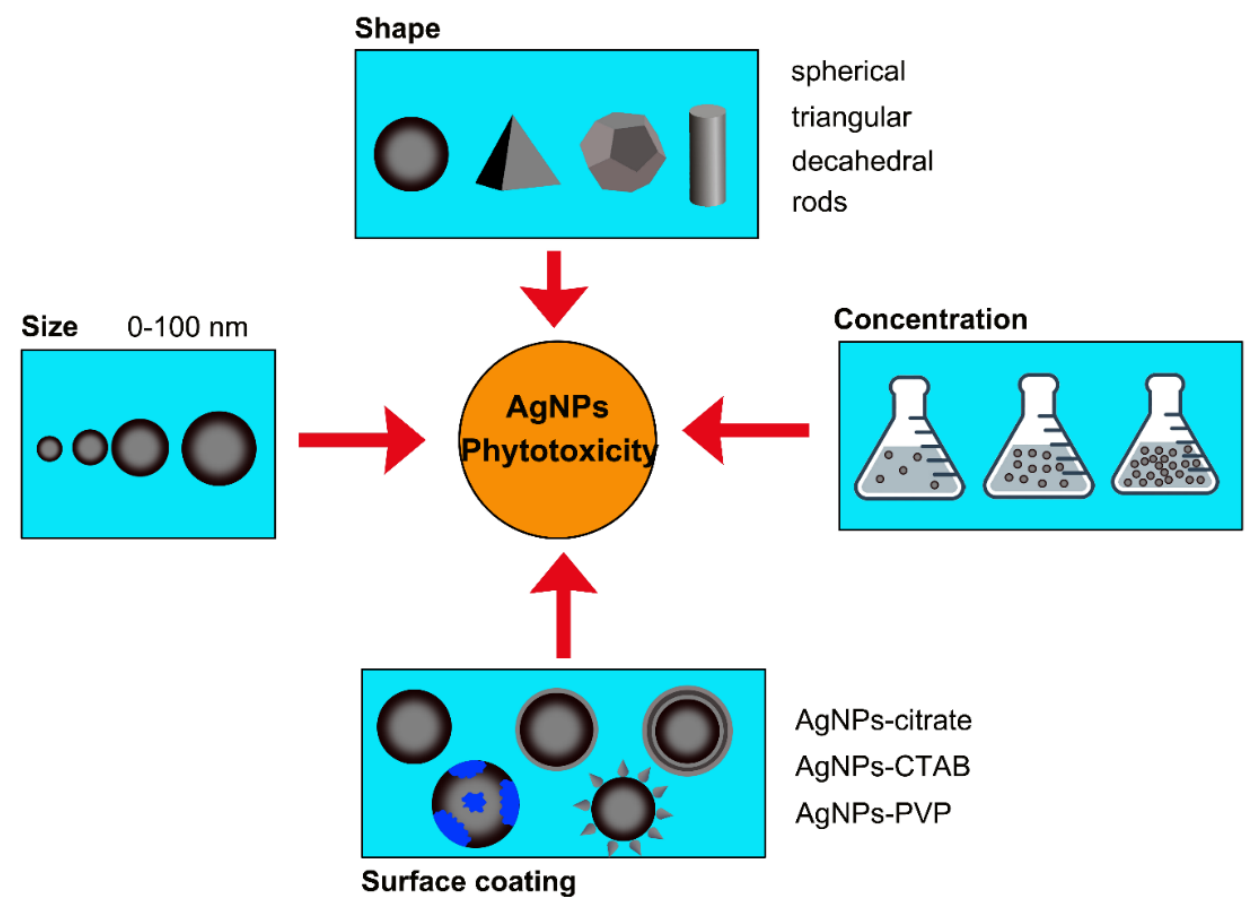

Figure 2. Schematic diagram showing AgNP-specific toxicity. The phytotoxicity of AgNPs is determined by AgNP properties, including size, shape, concentration, and surface coating of AgNPs.

Based on various studies on the phytotoxicity of AgNPs, it is evident that the interaction between plants and AgNPs is highly complicated and is not only dependent on the intrinsic properties of AgNPs, but is also influenced by plant species, developmental stages, different tissues, and sample preparation methodologies.

\section{Tolerance Mechanisms}

Phytotoxicity of AgNPs is highly associated with oxidative stress, which is caused by the production of excess amounts of ROS after AgNP exposure. To avoid the detrimental effects of 
ROS, a set of antioxidant defense mechanisms are activated in plant cells. The defense mechanism involves the activities of enzymatic antioxidants such as superoxide dismutase (SOD), catalase (CAT), ascorbate peroxidase (APX), guaiacol peroxidase (GPX), dehydroascorbate reductase (DHAR), and glutathione reductase (GR) $[100,136]$. As different types of ROS have different modes of action and exhibit different effects on cellular organelles of plant cells, they can be balanced or removed by specific antioxidant enzymes [36,137]. For example, there are three types of SOD in plant cells, including Fe-SOD, Mn-SOD, and Cu-Zn-SOD, and they can rapidly convert highly toxic ROS $\left(\mathrm{O}_{2}{ }^{\bullet-}\right)$ to less toxic species $\left(\mathrm{H}_{2} \mathrm{O}_{2}\right)$. CAT can convert $\mathrm{H}_{2} \mathrm{O}_{2}$ to $\mathrm{H}_{2} \mathrm{O}$ and $\mathrm{O}_{2}$. APX is able to convert $\mathrm{H}_{2} \mathrm{O}_{2}$ to $\mathrm{H}_{2} \mathrm{O}$ via ascorbate oxidation into monodehydroascorbate (MDA) and dehydroascorbate (DHA), both of which can be recycled to produce more ascorbate via the catalysis of MDA reductase (MADR) and DHAR [36]. Upon exposure to AgNPs, activities of these enzymatic antioxidants are elevated in plant cells to protect the cells from oxidative stress. For example, Zou et al. observed obvious oxidative damage to Wolffia globosa when the plants were exposed to $10 \mathrm{mg} / \mathrm{L}$ AgNPs. Meanwhile, the SOD activity was increased by 2.52 times, suggesting that the ROS-scavenging mechanism was activated [79]. Similarly, elevated SOD activity was also observed after AgNP exposure in tomatoes (Lycopersicon esculentum) [89]. Enhancement of peroxidase and catalase activity was also observed in Bacopa monnieri (Linn.) after AgNP treatment [74,83,138]. Jiang et al. found that the catalase activity in cells of Spirodela polyrhiza was significantly increased. Moreover, the SOD and peroxidase activity, and the antioxidant glutathione content were increased in a dose-dependent manner after exposure to 6-nm AgNPs [83]. In addition, Bagherzadeh Homaee and Ehsanpour examined the effects of AgNPs on potato (Solanum tuberosum L.) and observed that the activities of SOD, CAT, APX, and GR were all significantly increased in AgNP-treated plantlets [74].

Non-enzymatic antioxidants, such as anthocyanin, ascorbate, glutathione, and thiols, also contribute to the antioxidant defense mechanisms [100,136]. Anthocyanin is a kind of pigment that is implicated in tolerance to various biotic or abiotic stresses, such as herbivores and pathogens, drought, cold, ultraviolet (UV) radiation, and heavy metals [139]. Anthocyanin commonly serves as a non-enzymatic antioxidant to scavenge free radicals and chelate metals under stress conditions $[36,104,106,139]$. It was reported that anthocyanin accumulation was significantly induced in the spherical AgNP-treated Arabidopsis seedlings and was dose-dependent [85]. Similarly, anthocyanin accumulation was also significantly increased after exposure to higher concentrations of AgNPs in turnip [113]. In addition, other antioxidants such as ascorbic acid, carotenoids, and proline are also implicated in antioxidant defense responses of plants to AgNPs. Carotenoids are able to induce antioxidant activity and potentially reduce the toxic effects of ROS [140,141]. After AgNP exposure, a large increase in shoot carotenoid content was observed in rice, suggesting that plants employ carotenoid to reduce the effects of ROS caused by AgNPs [88]. An increase in ascorbic acid content was observed in Asparagus officinalis [99].

At the molecular level, the expression changes of genes that are associated with the response to AgNPs may underlie the antioxidant defense mechanisms of plants in response to AgNPs. Dimkpa et al. checked the transcription of a gene encoding metallothionein (MT), which is a cysteine-rich protein involved in detoxification by metal ion sequestration, and found that the expression of this gene was highly induced after AgNP treatment in wheat (Triticum aestivum L.) [52]. A gene expression study by microarray suggested that AgNP exposure to Arabidopsis led to the upregulation of genes that are associated with response to metal and oxidative stress, including genes encoding SOD, cytochrome P-450-dependent oxidase, and peroxidase, whereas AgNP exposure caused the downregulation of genes that are involved in response to pathogens and hormonal stimuli [51]. In Arabidopsis, the expressions of sulfur assimilation, glutathione biosynthesis, glutathione $S$-transferase, and glutathione reductase genes were significantly upregulated after exposure to AgNPs [84]. Sulfur metabolism in plants plays an important role in stress tolerance, especially in metal detoxification and in the maintenance of cellular redox homeostasis [117,142]. In addition, exposure of AgNPs to rice seedlings led to the differential transcription of genes associated with 
oxidative stress tolerance in shoots and roots, such as FSD1, MSD1, CSD1, CSD2, CATa, CATb, CATc, $A P X a$, and $A P X b[53]$.

\section{Potential Risk in Human Health Posed by AgNPs via Food Chain}

Plants are producers in the ecosystem and represent the primary trophic level in the food chain. Regarding the food safety issue, most of the harvested edible tissues or organs of vegetables or cereals are consumed by livestock and humans. Since AgNPs can be taken up and accumulated in plants, they can further pose a risk to human health through invading the food chain and ultimately transferring to the human body. Actually, it was demonstrated that AgNPs could cycle in the ecosystem through various trophic levels in an aquatic or terrestrial food chain $[9,100,143,144]$.

In aquatic ecosystems, planktonic algae as primary producers are located at the base of the aquatic food chain; therefore, algae were selected as the basic trophic level to investigate trophic transfer of AgNPs in a few studies. McTeer et al. investigated the bioavailability, toxicity, and trophic transfer of AgNPs between the alga Chlamydomonas reinhardtii and the grazing crustacean Daphnia magna, which belong to two different trophic levels. Nano Ag derived from AgNPs was accumulated into microalgae. After feeding on Ag-containing algae, Daphnia magna accumulated nano-derived Ag, confirming the trophic transfer of AgNPs between algae and Daphnia magna [145]. Similarly, Kalman et al. studied the bioaccumulation and trophic transfer of AgNPs in a simplified freshwater food chain comprising the green alga Chlorella vulgaris and Daphnia magna. After AgNPs were accumulated in algae, the Ag-contaminated algae were fed to Daphnia magna. Ag uptake in Daphnia magna was observed a few days later. Further analysis indicated that diet is the dominant pathway route of Ag uptake in Daphnia magna [144]. In addition, a recent study used paddy microcosm systems to estimate the trophic transfer of AgNP-citrate and AgNP-PVP among various trophic level organisms (aquatic plants, biofilms, river snails, and Chinese muddy loaches). After exposure, AgNPs rapidly coagulated and precipitated on the sediment. Stable isotope analysis indicated a close correlation between the Ag content in the prey and that in their corresponding predators, demonstrating the impact of AgNPs on ecological receptors and food chains [146].

In terrestrial food chains, studies on the potential trophic transfer of AgNPs remain scarce. However, the terrestrial trophic transfer of other metallic nanoparticles was investigated, such as AuNPs [147], $\mathrm{CeO}_{2}-\mathrm{NPs}$ [148], and $\mathrm{La}_{2} \mathrm{O}_{3}-\mathrm{NPs}$ [149]. In a simulated terrestrial food chain, tobacco hornworm (Manduca sexta) caterpillars were fed tomato leaf that were surface-contaminated with AuNPs. Later, the transfer of AuNPs from tomato to tobacco hornworm was observed [147]. Hence, these studies imply a possibility that AgNPs may also be transferred in the terrestrial food chains.

Both in vivo and in vitro studies demonstrated the toxicity of AgNPs on mammalian cells. For example, AgNP exposure reduced lung function and produced inflammatory lesions in the lungs of rat [150], and resulted in the accumulation of AgNPs in the olfactory bulbs and in the brain of rats [151]. Since AgNPs can be accumulated and transferred in the food chain, they may become dangerous to humans. Indeed, AgNPs exposure to human cells can stimulate inflammatory and immunological responses, cause oxidative stress, and lead to cellular damage [152-154]. Therefore, there is an urgent need to increase our understanding of the bioaccumulation and trophic transfer of AgNPs in the food chain, which is critical for assessing and mitigating their potential harm to human health.

\section{Conclusions and Perspectives}

Due to the immense application of AgNPs in various fields in modern society, their dispersal and permeation into the ecosystem became inevitable. Hence, a great concern is arising related to the potential risk of destruction in the ecosystem, decline in food quality and yield, and even undermining of human health imposed by AgNPs. To this concern, understanding how AgNPs transfer through the ecosystem and exert impacts on plants is of crucial importance. During the past decade, the research communities undertook the responsibility to increase our knowledge of the impacts of AgNPs on plants, by carrying out numerous studies regarding the interactions between plants and AgNPs. 
Most of these studies revealed the detrimental effects of AgNPs on plants in various aspects, including at morphological, physiological, cellular, and molecular levels. However, a few studies reported the positive effects of AgNPs on plant growth and development. These contradictory results indicate the complexity of the responses of plants to AgNPs, which are not only determined by the properties of AgNPs (size, concentration, shape, surface coating, Ag chemical form, etc.), but are also dependent on the plant system used (species, tissue, organ, developmental stage, etc.) and experimental methodology (medium, exposure method, exposure time, etc.)

In response to AgNPs, it is rational that multiple detoxification strategies may be activated; different plant species may employ different detoxification mechanisms to eliminate the toxic effects of AgNPs. Therefore, it is difficult to make a general conclusion on how different detoxification pathways in response to diverse AgNPs conditions are activated in different plant species. To address this issue, it is necessary to use representative species, such as the commonly used model plant Arabidopsis, to evaluate the phytotoxicity of AgNPs and tolerance mechanisms. Meanwhile, the establishment of a standardized methodology is required to conduct normalized AgNP exposure, thereby allowing comparisons between different species.

Although joint efforts by research communities generated essential knowledge of the impacts of AgNPs on plants, most of these experimental outcomes were based on laboratory experiments under controlled conditions that are likely far from field conditions, such as the exposure method (hydroponic vs. soil), exposure dosage, and time (acute vs. chronic). Therefore, it is hard to predict whether the phytotoxicity of AgNPs and tolerance mechanisms under laboratory conditions are the same as under field conditions. To this end, the establishment of well-designed, plant life-cycle experimental systems under environmentally realistic conditions is required to accurately evaluate the impacts of AgNPs on plants and to generate environmentally relevant implications.

In addition, most studies performed during the last decade focused on the impacts of AgNPs on plants at the morphological and physiological levels; however, the profound impacts of AgNPs at the molecular level did not draw enough attention. Benefits from the development of systems biology and multiple omics methodologies, such as transcriptomics, proteomics, and metabonomics, can be employed in future studies to comprehensively assess the phytotoxicity mechanism of AgNPs and tolerance mechanisms in plants.

Author Contributions: Z.C. conceived and designed the topic and content. A.Y. and Z.C. wrote the article.

Acknowledgments: The authors thank funding supports from the NIE AcRF grant (RI 8/16 CZ) and the Singapore National Parks Board grant (NParks-Phytoremediation).

Conflicts of Interest: The authors declare no conflict of interest.

\section{References}

1. Vance, M.E.; Kuiken, T.; Vejerano, E.P.; McGinnis, S.P.; Hochella, M.F., Jr.; Rejeski, D.; Hull, M.S. Nanotechnology in the real world: Redeveloping the nanomaterial consumer products inventory. Beilstein J. Nanotechnol. 2015, 6, 1769-1780. [CrossRef] [PubMed]

2. Ahamed, M.; Posgai, R.; Gorey, T.J.; Nielsen, M.; Hussain, S.M.; Rowe, J.J. Silver nanoparticles induced heat shock protein 70, oxidative stress and apoptosis in Drosophila melanogaster. Toxicol. Appl. Pharm. 2010, 242, 263-269. [CrossRef] [PubMed]

3. Durán, N.; Marcato, P.D.; De Souza, G.I.; Alves, O.L.; Esposito, E. Antibacterial effect of silver nanoparticles produced by fungal process on textile fabrics and their effluent treatment. J. Biomed. Nanotechnol. 2007, 3, 203-208. [CrossRef]

4. Pandian, A.M.K.; Karthikeyan, C.; Rajasimman, M.; Dinesh, M.G. Synthesis of silver nanoparticle and its application. Ecotoxicol. Environ. Saf. 2015, 121, 211-217. [CrossRef] [PubMed]

5. Rai, M.; Yadav, A.; Gade, A. Silver nanoparticles as a new generation of antimicrobials. Biotechnol. Adv. 2009, 27, 76-83. [CrossRef] [PubMed]

6. Quang Huy, T.; Van Quy, N.; Anh-Tuan, L. Silver nanoparticles: Synthesis, properties, toxicology, applications and perspectives. Adv. Nat. Sci. Nanosci. Nanotechnol. 2013, 4, 033001. [CrossRef] 
7. Zhang, C.; Hu, Z.; Li, P.; Gajaraj, S. Governing factors affecting the impacts of silver nanoparticles on wastewater treatment. Sci. Total Environ. 2016, 572, 852-873. [CrossRef] [PubMed]

8. Steinitz, B.; Bilavendran, A.D. Thiosulfate stimulates growth and alleviates silver and copper toxicity in tomato root cultures. Plant Cell Tissue Organ Cult. 2011, 107, 355-363. [CrossRef]

9. Monica, R.C.; Cremonini, R. Nanoparticles and higher plants. Caryologia 2009, 62, 161-165. [CrossRef]

10. Alavi, S.; Dehpour, A. Evaluation of the nanosilver colloidal solution in comparison with the registered fungicide to control greenhouse cucumber downy mildew disease in the north of Iran. In Proceedings of the VI International Postharvest Symposium, Antalya, Turkey, 11 November 2010; pp. 1643-1646.

11. Sah, S.; Sorooshzadeh, A.; Rezazadeh, H.; Naghdibadi, H. Effect of nano silver and silver nitrate on seed yield of borage. J. Med. Plants Res. 2011, 5, 706-710.

12. Vinković, T.; Novák, O.; Strnad, M.; Goessler, W.; Jurašin, D.D.; Parađiković, N.; Vrček, I.V. Cytokinin response in pepper plants (Capsicum annuum L.) exposed to silver nanoparticles. Environ. Res. 2017, 156, 10-18. [CrossRef]

13. Hedberg, J.; Skoglund, S.; Karlsson, M.-E.; Wold, S.; Odnevall Wallinder, I.; Hedberg, Y. Sequential studies of silver released from silver nanoparticles in aqueous media simulating sweat, laundry detergent solutions and surface water. Environ. Sci. Technol. 2014, 48, 7314-7322. [CrossRef] [PubMed]

14. Künniger, T.; Gerecke, A.C.; Ulrich, A.; Huch, A.; Vonbank, R.; Heeb, M.; Wichser, A.; Haag, R.; Kunz, P.; Faller, M. Release and environmental impact of silver nanoparticles and conventional organic biocides from coated wooden façades. Environ. Pollut. 2014, 184, 464-471. [CrossRef] [PubMed]

15. Lombi, E.; Donner, E.; Scheckel, K.G.; Sekine, R.; Lorenz, C.; Goetz, N.V.; Nowack, B. Silver speciation and release in commercial antimicrobial textiles as influenced by washing. Chemosphere 2014, 111, 352-358. [CrossRef] [PubMed]

16. Sun, T.Y.; Gottschalk, F.; Hungerbühler, K.; Nowack, B. Comprehensive probabilistic modelling of environmental emissions of engineered nanomaterials. Environ. Pollut. 2014, 185, 69-76. [CrossRef] [PubMed]

17. Gottschalk, F.; Sonderer, T.; Scholz, R.W.; Nowack, B. Modeled environmental concentrations of engineered nanomaterials $\left(\mathrm{TiO}_{2}, \mathrm{ZnO}, \mathrm{Ag}, \mathrm{CNT}\right.$, Fullerenes) for different regions. Environ. Sci. Technol. 2009, 43, 9216-9222. [CrossRef] [PubMed]

18. Mueller, N.C.; Nowack, B. Exposure modeling of engineered nanoparticles in the environment. Environ. Sci. Technol. 2008, 42, 4447-4453. [CrossRef] [PubMed]

19. Benn, T.M.; Westerhoff, P. Nanoparticle silver released into water from commercially available sock fabrics. Environ. Sci. Technol. 2008, 42, 4133-4139. [CrossRef] [PubMed]

20. Kaegi, R.; Sinnet, B.; Zuleeg, S.; Hagendorfer, H.; Mueller, E.; Vonbank, R.; Boller, M.; Burkhardt, M. Release of silver nanoparticles from outdoor facades. Environ. Pollut. 2010, 158, 2900-2905. [CrossRef] [PubMed]

21. Gottschalk, F.; Nowack, B. The release of engineered nanomaterials to the environment. J. Environ. Monit. 2011, 13, 1145-1155. [CrossRef] [PubMed]

22. Hoque, M.E.; Khosravi, K.; Newman, K.; Metcalfe, C.D. Detection and characterization of silver nanoparticles in aqueous matrices using asymmetric-flow field flow fractionation with inductively coupled plasma mass spectrometry. J. Chromatogr. A 2012, 1233, 109-115. [CrossRef] [PubMed]

23. Blaser, S.A.; Scheringer, M.; MacLeod, M.; Hungerbühler, K. Estimation of cumulative aquatic exposure and risk due to silver: Contribution of nano-functionalized plastics and textiles. Sci. Total Environ. 2008, 390, 396-409. [CrossRef] [PubMed]

24. Gottschalk, F.; Sonderer, T.; Scholz, R.W.; Nowack, B. Possibilities and limitations of modeling environmental exposure to engineered nanomaterials by probabilistic material flow analysis. Environ. Toxicol. Chem. 2010, 29, 1036-1048. [CrossRef] [PubMed]

25. Fabrega, J.; Luoma, S.N.; Tyler, C.R.; Galloway, T.S.; Lead, J.R. Silver nanoparticles: Behaviour and effects in the aquatic environment. Environ. Int. 2011, 37, 517-531. [CrossRef] [PubMed]

26. Kaegi, R.; Voegelin, A.; Sinnet, B.; Zuleeg, S.; Hagendorfer, H.; Burkhardt, M.; Siegrist, H. Behavior of metallic silver nanoparticles in a pilot wastewater treatment plant. Environ. Sci. Technol. 2011, 45, 3902-3908. [CrossRef] [PubMed]

27. Dietz, K.-J.; Herth, S. Plant nanotoxicology. Trends Plant Sci. 2011, 16, 582-589. [CrossRef] [PubMed]

28. Lazareva, A.; Keller, A.A. Estimating potential life cycle releases of engineered nanomaterials from wastewater treatment plants. ACS Sustain. Chem. Eng. 2014, 2, 1656-1665. [CrossRef] 
29. Ma, X.; Geiser-Lee, J.; Deng, Y.; Kolmakov, A. Interactions between engineered nanoparticles (ENPs) and plants: Phytotoxicity, uptake and accumulation. Sci. Total Environ. 2010, 408, 3053-3061. [CrossRef] [PubMed]

30. Maynard, A.D.; Warheit, D.B.; Philbert, M.A. The new toxicology of sophisticated materials: Nanotoxicology and beyond. Toxicol. Sci. 2011, 120, S109-S129. [CrossRef] [PubMed]

31. Beer, C.; Foldbjerg, R.; Hayashi, Y.; Sutherland, D.S.; Autrup, H. Toxicity of silver nanoparticles-Nanoparticle or silver ion? Toxicol. Lett. 2012, 208, 286-292. [CrossRef] [PubMed]

32. Colman, B.P.; Arnaout, C.L.; Anciaux, S.; Gunsch, C.K.; Hochella, M.F., Jr.; Kim, B.; Lowry, G.V.; McGill, B.M.; Reinsch, B.C.; Richardson, C.J.; et al. Low concentrations of silver nanoparticles in biosolids cause adverse ecosystem responses under realistic field scenario. PLoS ONE 2013, 8, e57189. [CrossRef] [PubMed]

33. Cvjetko, P.; Zovko, M.; Štefanić, P.P.; Biba, R.; Tkalec, M.; Domijan, A.-M.; Vrček, I.V.; Letofsky-Papst, I.; Šikić, S.; Balen, B. Phytotoxic effects of silver nanoparticles in tobacco plants. Environ. Sci. Pollut. Res. 2018, 25, 5590-5602. [CrossRef] [PubMed]

34. Moreno-Garrido, I.; Pérez, S.; Blasco, J. Toxicity of silver and gold nanoparticles on marine microalgae. Mar. Environ. Res. 2015, 111, 60-73. [CrossRef] [PubMed]

35. Ratte, H.T. Bioaccumulation and toxicity of silver compounds: A review. Environ. Toxicol. Chem. 1999, 18, 89-108. [CrossRef]

36. Ma, C.; White, J.C.; Dhankher, O.P.; Xing, B. Metal-based nanotoxicity and detoxification pathways in higher plants. Environ. Sci. Technol. 2015, 49, 7109-7122. [CrossRef] [PubMed]

37. Maurer-Jones, M.A.; Gunsolus, I.L.; Murphy, C.J.; Haynes, C.L. Toxicity of engineered nanoparticles in the environment. Anal. Chem. 2013, 85, 3036-3049. [CrossRef] [PubMed]

38. Gardea-Torresdey, J.L.; Rico, C.M.; White, J.C. Trophic transfer, transformation, and impact of engineered nanomaterials in terrestrial environments. Environ. Sci. Technol. 2014, 48, 2526-2540. [CrossRef] [PubMed]

39. Geisler-Lee, J.; Wang, Q.; Yao, Y.; Zhang, W.; Geisler, M.; Li, K.; Huang, Y.; Chen, Y.; Kolmakov, A.; Ma, X. Phytotoxicity, accumulation and transport of silver nanoparticles by Arabidopsis thaliana. Nanotoxicology 2013, 7, 323-337. [CrossRef] [PubMed]

40. Geisler-Lee, J.; Brooks, M.; Gerfen, J.R.; Wang, Q.; Fotis, C.; Sparer, A.; Ma, X.; Berg, R.H.; Geisler, M. Reproductive toxicity and life history study of silver nanoparticle effect, uptake and transport in Arabidopsis thaliana. Nanomaterials 2014, 4, 301-318. [CrossRef] [PubMed]

41. Miralles, P.; Church, T.L.; Harris, A.T. Toxicity, uptake, and translocation of engineered nanomaterials in vascular plants. Environ. Sci. Technol. 2012, 46, 9224-9239. [CrossRef] [PubMed]

42. Aslani, F.; Bagheri, S.; Muhd Julkapli, N.; Juraimi, A.S.; Hashemi, F.S.G.; Baghdadi, A. Effects of engineered nanomaterials on plants growth: An overview. Sci. World J. 2014, 2014. [CrossRef] [PubMed]

43. Tripathi, D.K.; Tripathi, A.; Singh, S.; Singh, Y.; Vishwakarma, K.; Yadav, G.; Sharma, S.; Singh, V.K.; Mishra, R.K.; Upadhyay, R.G.; et al. Uptake, accumulation and toxicity of silver nanoparticle in autotrophic plants, and heterotrophic microbes: A concentric review. Front. Microbiol. 2017, 8. [CrossRef] [PubMed]

44. Navarro, E.; Baun, A.; Behra, R.; Hartmann, N.B.; Filser, J.; Miao, A.-J.; Quigg, A.; Santschi, P.H.; Sigg, L. Environmental behavior and ecotoxicity of engineered nanoparticles to algae, plants, and fungi. Ecotoxicology 2008, 17, 372-386. [CrossRef] [PubMed]

45. Carpita, N.C.; Gibeaut, D.M. Structural models of primary cell walls in flowering plants: Consistency of molecular structure with the physical properties of the walls during growth. Plant J. 1993, 3, 1-30. [CrossRef] [PubMed]

46. Heinlein, M.; Epel, B.L. Macromolecular transport and signaling through plasmodesmata. Int. Rev. Cytol. 2004. [CrossRef]

47. Lucas, W.J.; Lee, J.-Y. Plasmodesmata as a supracellular control network in plants. Nat. Rev. Mol. Cell Biol. 2004, 5, 712. [CrossRef] [PubMed]

48. Larue, C.; Castillo-Michel, H.; Sobanska, S.; Cécillon, L.; Bureau, S.; Barthès, V.; Ouerdane, L.; Carrière, M.; Sarret, G. Foliar exposure of the crop Lactuca sativa to silver nanoparticles: Evidence for internalization and changes in Ag speciation. J. Hazard. Mater. 2014, 264, 98-106. [CrossRef] [PubMed]

49. Li, C.-C.; Dang, F.; Li, M.; Zhu, M.; Zhong, H.; Hintelmann, H.; Zhou, D.-M. Effects of exposure pathways on the accumulation and phytotoxicity of silver nanoparticles in soybean and rice. Nanotoxicology 2017, 11, 699-709. [CrossRef] [PubMed] 
50. Jiang, H.-S.; Li, M.; Chang, F.-Y.; Li, W.; Yin, L.-Y. Physiological analysis of silver nanoparticles and $\mathrm{AgNO}_{3}$ toxicity to Spirodela polyrhiza. Environ. Toxicol. Chem. 2012, 31, 1880-1886. [CrossRef] [PubMed]

51. Kaveh, R.; Li, Y.-S.; Ranjbar, S.; Tehrani, R.; Brueck, C.L.; Van Aken, B. Changes in Arabidopsis thaliana gene expression in response to silver nanoparticles and silver ions. Environ. Sci. Technol. 2013, 47, 10637-10644. [CrossRef] [PubMed]

52. Dimkpa, C.O.; McLean, J.E.; Martineau, N.; Britt, D.W.; Haverkamp, R.; Anderson, A.J. Silver nanoparticles disrupt wheat (Triticum aestivum L.) growth in a sand matrix. Environ. Sci. Technol. 2013, 47, 1082-1090. [CrossRef] [PubMed]

53. Nair, P.M.G.; Chung, I.M. Physiological and molecular level effects of silver nanoparticles exposure in rice (Oryza sativa L.) seedlings. Chemosphere 2014, 112, 105-113. [CrossRef] [PubMed]

54. Stampoulis, D.; Sinha, S.K.; White, J.C. Assay-dependent phytotoxicity of nanoparticles to plants. Environ. Sci. Technol. 2009, 43, 9473-9479. [CrossRef] [PubMed]

55. Qian, H.; Peng, X.; Han, X.; Ren, J.; Sun, L.; Fu, Z. Comparison of the toxicity of silver nanoparticles and silver ions on the growth of terrestrial plant model Arabidopsis thaliana. J. Environ. Sci. 2013, 25, 1947-1956. [CrossRef]

56. Amooaghaie, R.; Tabatabaei, F.; Ahadi, A.-M. Role of hematin and sodium nitroprusside in regulating Brassica nigra seed germination under nanosilver and silver nitrate stresses. Ecotoxicol. Environ. Saf. 2015, 113, 259-270. [CrossRef] [PubMed]

57. Gubbins, E.J.; Batty, L.C.; Lead, J.R. Phytotoxicity of silver nanoparticles to Lemna minor L. Environ. Pollut. 2011, 159, 1551-1559. [CrossRef] [PubMed]

58. Lee, W.-M.; Kwak, J.I.; An, Y.-J. Effect of silver nanoparticles in crop plants Phaseolus radiatus and Sorghum bicolor: Media effect on phytotoxicity. Chemosphere 2012, 86, 491-499. [CrossRef] [PubMed]

59. Yin, L.; Cheng, Y.; Espinasse, B.; Colman, B.P.; Auffan, M.; Wiesner, M.; Rose, J.; Liu, J.; Bernhardt, E.S. More than the Ions: The effects of silver nanoparticles on Lolium multiflorum. Environ. Sci. Technol. 2011, 45, 2360-2367. [CrossRef] [PubMed]

60. Ejaz, M.; Raja, N.I.; Ahmad, M.S.; Hussain, M.; Iqbal, M. Effect of silver nanoparticles and silver nitrate on growth of rice under biotic stress. IET Nanobiotechnol. 2018. [CrossRef] [PubMed]

61. Yang, J.; Jiang, F.; Ma, C.; Rui, Y.; Rui, M.; Adeel, M.; Cao, W.; Xing, B. Alteration of crop yield and quality of wheat upon exposure to silver nanoparticles in a life cycle study. J. Agric. Food Chem. 2018, 66, 2589-2597. [CrossRef] [PubMed]

62. Al-Huqail, A.A.; Hatata, M.M.; Al-Huqail, A.A.; Ibrahim, M.M. Preparation, characterization of silver phyto nanoparticles and their impact on growth potential of Lupinus termis L. seedlings. Saudi J. Biol. Sci. 2018, 25, 313-319. [CrossRef] [PubMed]

63. Abdelsalam, N.R.; Abdel-Megeed, A.; Ali, H.M.; Salem, M.Z.M.; Al-Hayali, M.F.A.; Elshikh, M.S. Genotoxicity effects of silver nanoparticles on wheat (Triticum aestivum L.) root tip cells. Ecotoxicol. Environ. Saf. 2018, 155, 76-85. [CrossRef] [PubMed]

64. Liang, L.; Tang, H.; Deng, Z.; Liu, Y.; Chen, X.; Wang, H. Ag nanoparticles inhibit the growth of the bryophyte, Physcomitrella patens. Ecotoxicol. Environ. Saf. 2018, 164, 739-748. [CrossRef] [PubMed]

65. Pereira, S.P.P.; Jesus, F.; Aguiar, S.; de Oliveira, R.; Fernandes, M.; Ranville, J.; Nogueira, A.J.A. Phytotoxicity of silver nanoparticles to Lemna minor: Surface coating and exposure period-related effects. Sci. Total Environ. 2018, 618, 1389-1399. [CrossRef] [PubMed]

66. Tripathi, D.K.; Singh, S.; Singh, S.; Srivastava, P.K.; Singh, V.P.; Singh, S.; Prasad, S.M.; Singh, P.K.; Dubey, N.K.; Pandey, A.C.; et al. Nitric oxide alleviates silver nanoparticles (AgNPs)-induced phytotoxicity in Pisum sativum seedlings. Plant Physiol. Biochem. 2017, 110, 167-177. [CrossRef] [PubMed]

67. Cvjetko, P.; Milošić, A.; Domijan, A.-M.; Vinković Vrček, I.; Tolić, S.; Peharec Štefanić, P.; Letofsky-Papst, I.; Tkalec, M.; Balen, B. Toxicity of silver ions and differently coated silver nanoparticles in Allium cepa roots. Ecotoxicol. Environ. Saf. 2017, 137, 18-28. [CrossRef] [PubMed]

68. Saha, N.; Dutta Gupta, S. Low-dose toxicity of biogenic silver nanoparticles fabricated by Swertia chirata on root tips and flower buds of Allium cepa. J. Hazard. Mater. 2017, 330, 18-28. [CrossRef] [PubMed]

69. Jasim, B.; Thomas, R.; Mathew, J.; Radhakrishnan, E.K. Plant growth and diosgenin enhancement effect of silver nanoparticles in Fenugreek (Trigonella foenum-graecum L.). Saudi Pharm. J. 2017, 25, 443-447. [CrossRef] [PubMed] 
70. Sun, J.; Wang, L.; Li, S.; Yin, L.; Huang, J.; Chen, C. Toxicity of silver nanoparticles to Arabidopsis: Inhibition of root gravitropism by interfering with auxin pathway. Environ. Toxicol. Chem. 2017, 36, 2773-2780. [CrossRef] [PubMed]

71. Vishwakarma, K.; Upadhyay, N.; Singh, J.; Liu, S.; Singh, V.P.; Prasad, S.M.; Chauhan, D.K.; Tripathi, D.K.; Sharma, S. Differential phytotoxic impact of plant mediated silver nanoparticles (AgNPs) and silver nitrate $\left(\mathrm{AgNO}_{3}\right)$ on Brassica sp. Front. Plant Sci. 2017, 8, 1501. [CrossRef] [PubMed]

72. Wang, P.; Lombi, E.; Sun, S.; Scheckel, K.G.; Malysheva, A.; McKenna, B.A.; Menzies, N.W.; Zhao, F.-J.; Kopittke, P.M. Characterizing the uptake, accumulation and toxicity of silver sulfide nanoparticles in plants. Environ. Sci. 2017, 4, 448-460. [CrossRef]

73. Abd-Alla, M.H.; Nafady, N.A.; Khalaf, D.M. Assessment of silver nanoparticles contamination on faba bean-Rhizobium leguminosarum bv. viciae-Glomus aggregatum symbiosis: Implications for induction of autophagy process in root nodule. Agric. Ecosyst. Environ. 2016, 218, 163-177. [CrossRef]

74. Bagherzadeh Homaee, M.; Ehsanpour, A.A. Silver nanoparticles and silver ions: Oxidative stress responses and toxicity in potato (Solanum tuberosum L.) grown in vitro. Hortic. Environ. Biotechnol. 2016, 57, 544-553. [CrossRef]

75. Mehta, C.M.; Srivastava, R.; Arora, S.; Sharma, A.K. Impact assessment of silver nanoparticles on plant growth and soil bacterial diversity. 3 Biotech 2016, 6, 254. [CrossRef]

76. Zuverza-Mena, N.; Armendariz, R.; Peralta-Videa, J.R.; Gardea-Torresdey, J.L. Effects of silver nanoparticles on radish sprouts: Root growth reduction and modifications in the nutritional value. Front. Plant Sci. 2016, 7, 90. [CrossRef] [PubMed]

77. Sosan, A.; Svistunenko, D.; Straltsova, D.; Tsiurkina, K.; Smolich, I.; Lawson, T.; Subramaniam, S.; Golovko, V.; Anderson, D.; Sokolik, A.; et al. Engineered silver nanoparticles are sensed at the plasma membrane and dramatically modify the physiology of Arabidopsis thaliana plants. Plant J. 2016, 85, 245-257. [CrossRef] [PubMed]

78. Wen, Y.; Zhang, L.; Chen, Z.; Sheng, X.; Qiu, J.; Xu, D. Co-exposure of silver nanoparticles and chiral herbicide imazethapyr to Arabidopsis thaliana: Enantioselective effects. Chemosphere 2016, 145, 207-214. [CrossRef] [PubMed]

79. Zou, X.; Li, P.; Huang, Q.; Zhang, H. The different response mechanisms of Wolffia globosa: Light-induced silver nanoparticle toxicity. Aquat. Toxicol. 2016, 176, 97-105. [CrossRef] [PubMed]

80. Kohan-Baghkheirati, E.; Geisler-Lee, J. Gene expression, protein function and pathways of Arabidopsis thaliana responding to silver nanoparticles in comparison to silver ions, cold, salt, drought, and heat. Nanomaterials 2015, 5, 436-467. [CrossRef] [PubMed]

81. García-Sánchez, S.; Bernales, I.; Cristobal, S. Early response to nanoparticles in the Arabidopsis transcriptome compromises plant defence and root-hair development through salicylic acid signalling. BMC Genom. 2015, 16, 341. [CrossRef] [PubMed]

82. Wang, P.; Menzies, N.W.; Lombi, E.; Sekine, R.; Blamey, F.P.C.; Hernandez-Soriano, M.C.; Cheng, M.; Kappen, P.; Peijnenburg, W.J.G.M.; Tang, C.; et al. Silver sulfide nanoparticles ( $\mathrm{Ag}_{2} \mathrm{~S}-\mathrm{NPs}$ ) are taken up by plants and are phytotoxic. Nanotoxicology 2015, 9, 1041-1049. [CrossRef] [PubMed]

83. Jiang, H.-S.; Qiu, X.-N.; Li, G.-B.; Li, W.; Yin, L.-Y. Silver nanoparticles induced accumulation of reactive oxygen species and alteration of antioxidant systems in the aquatic plant Spirodela polyrhiza. Environ. Toxicol. Chem. 2014, 33, 1398-1405. [CrossRef] [PubMed]

84. Nair, P.M.G.; Chung, I.M. Assessment of silver nanoparticle-induced physiological and molecular changes in Arabidopsis thaliana. Environ. Sci. Pollut. Res. 2014, 21, 8858-8869. [CrossRef] [PubMed]

85. Syu, Y.-Y.; Hung, J.-H.; Chen, J.-C.; Chuang, H.-W. Impacts of size and shape of silver nanoparticles on Arabidopsis plant growth and gene expression. Plant Physiol. Biochem. 2014, 83, 57-64. [CrossRef] [PubMed]

86. Thuesombat, P.; Hannongbua, S.; Akasit, S.; Chadchawan, S. Effect of silver nanoparticles on rice (Oryza sativa L. cv. KDML 105) seed germination and seedling growth. Ecotoxicol. Environ. Saf. 2014, 104, 302-309. [CrossRef] [PubMed]

87. Pokhrel, L.R.; Dubey, B. Evaluation of developmental responses of two crop plants exposed to silver and zinc oxide nanoparticles. Sci. Total Environ. 2013, 452-453, 321-332. [CrossRef] [PubMed]

88. Mirzajani, F.; Askari, H.; Hamzelou, S.; Farzaneh, M.; Ghassempour, A. Effect of silver nanoparticles on Oryza sativa L. and its rhizosphere bacteria. Ecotoxicol. Environ. Saf. 2013, 88, 48-54. [CrossRef] [PubMed] 
89. Song, U.; Jun, H.; Waldman, B.; Roh, J.; Kim, Y.; Yi, J.; Lee, E.J. Functional analyses of nanoparticle toxicity: A comparative study of the effects of $\mathrm{TiO}_{2}$ and $\mathrm{Ag}$ on tomatoes (Lycopersicon esculentum). Ecotoxicol. Environ. Saf. 2013, 93, 60-67. [CrossRef] [PubMed]

90. Wang, J.; Koo, Y.; Alexander, A.; Yang, Y.; Westerhof, S.; Zhang, Q.; Schnoor, J.L.; Colvin, V.L.; Braam, J.; Alvarez, P.J.J. Phytostimulation of Poplars and Arabidopsis exposed to silver nanoparticles and $\mathrm{Ag}^{+}$at sublethal concentrations. Environ. Sci. Technol. 2013, 47, 5442-5449. [CrossRef] [PubMed]

91. Yin, L.; Colman, B.P.; McGill, B.M.; Wright, J.P.; Bernhardt, E.S. Effects of silver nanoparticle exposure on germination and early growth of eleven wetland plants. PLoS ONE 2012, 7, e47674. [CrossRef] [PubMed]

92. Hawthorne, J.; Musante, C.; Sinha, S.K.; White, J.C. Accumulation and phytotoxicity of engineered nanoparticles to Cucurbita Pepo. Int. J. Phytoremediat. 2012, 14, 429-442. [CrossRef] [PubMed]

93. Musante, C.; White, J.C. Toxicity of silver and copper to Cucurbita pepo: Differential effects of nano and bulk-size particles. Environ. Toxicol. 2012, 27, 510-517. [CrossRef] [PubMed]

94. Patlolla, A.K.; Berry, A.; May, L.; Tchounwou, P.B. Genotoxicity of silver nanoparticles in Vicia faba: A pilot study on the environmental monitoring of nanoparticles. Int. J. Environ. Res. Public Health 2012, 9, 1649. [CrossRef] [PubMed]

95. Sharma, P.; Bhatt, D.; Zaidi, M.G.H.; Saradhi, P.P.; Khanna, P.K.; Arora, S. Silver nanoparticle-mediated enhancement in growth and antioxidant status of Brassica juncea. Appl. Biochem. Biotech. 2012, 167, 2225-2233. [CrossRef] [PubMed]

96. Mazumdar, H.; Ahmed, G. Phytotoxicity effect of silver nanoparticles on Oryza sativa. IJ Chemtech. Res. 2011, 3, 1494-1500.

97. Panda, K.K.; Achary, V.M.M.; Krishnaveni, R.; Padhi, B.K.; Sarangi, S.N.; Sahu, S.N.; Panda, B.B. In vitro biosynthesis and genotoxicity bioassay of silver nanoparticles using plants. Toxicol. In Vitro 2011, 25, 1097-1105. [CrossRef] [PubMed]

98. Kumari, M.; Mukherjee, A.; Chandrasekaran, N. Genotoxicity of silver nanoparticles in Allium cepa. Sci. Total Environ. 2009, 407, 5243-5246. [CrossRef] [PubMed]

99. An, J.; Zhang, M.; Wang, S.; Tang, J. Physical, chemical and microbiological changes in stored green asparagus spears as affected by coating of silver nanoparticles-PVP. LWT Food Sci. Technol. 2008, 41, 1100-1107. [CrossRef]

100. Tripathi, D.K.; Singh, S.; Singh, S.; Pandey, R.; Singh, V.P.; Sharma, N.C.; Prasad, S.M.; Dubey, N.K.; Chauhan, D.K. An overview on manufactured nanoparticles in plants: Uptake, translocation, accumulation and phytotoxicity. Plant Physiol. Biochem. 2017, 110, 2-12. [CrossRef] [PubMed]

101. Mazumdar, H. Comparative assessment of the adverse effect of silver nanoparticles to Vigna radiata and Brassica campestris crop plants. Int. J. Eng. Res. Appl. 2014, 4, 118-124.

102. Yan, A.; Chen, Z. Detection methods of nanoparticles in plant tissues. In New Visions in Plant Science; IntechOpen: London, UK, 2018.

103. Nair, R.; Varghese, S.H.; Nair, B.G.; Maekawa, T.; Yoshida, Y.; Kumar, D.S. Nanoparticulate material delivery to plants. Plant Sci. 2010, 179, 154-163. [CrossRef]

104. Mourato, M.; Reis, R.; Martins, L.L. Characterization of plant antioxidative system in response to abiotic stresses: A focus on heavy metal toxicity. In Advances in Selected Plant Physiology Aspects; IntechOpen: London, UK, 2012.

105. Møller, I.M.; Jensen, P.E.; Hansson, A. Oxidative modifications to cellular components in plants. Annu. Rev. Plant Biol. 2007, 58, 459-481. [CrossRef] [PubMed]

106. Carocho, M.; Ferreira, I.C.F.R. A review on antioxidants, prooxidants and related controversy: Natural and synthetic compounds, screening and analysis methodologies and future perspectives. Food Chem. Toxicol. 2013, 51, 15-25. [CrossRef] [PubMed]

107. Capaldi Arruda, S.C.; Diniz Silva, A.L.; Moretto Galazzi, R.; Antunes Azevedo, R.; Zezzi Arruda, M.A. Nanoparticles applied to plant science: A review. Talanta 2015, 131, 693-705. [CrossRef] [PubMed]

108. Sen Raychaudhuri, S.; Deng, X.W. The role of superoxide dismutase in combating oxidative stress in higher plants. Bot. Rev. 2000, 66, 89-98. [CrossRef]

109. Yuan, L.; Richardson, C.J.; Ho, M.; Willis, C.W.; Colman, B.P.; Wiesner, M.R. Stress responses of aquatic plants to silver nanoparticles. Environ. Sci. Technol. 2018, 52, 2558-2565. [CrossRef] [PubMed] 
110. Speranza, A.; Crinelli, R.; Scoccianti, V.; Taddei, A.R.; Iacobucci, M.; Bhattacharya, P.; Ke, P.C. In vitro toxicity of silver nanoparticles to kiwifruit pollen exhibits peculiar traits beyond the cause of silver ion release. Environ. Pollut. 2013, 179, 258-267. [CrossRef] [PubMed]

111. De La Torre-Roche, R.; Hawthorne, J.; Musante, C.; Xing, B.; Newman, L.A.; Ma, X.; White, J.C. Impact of Ag nanoparticle exposure on p, $\mathrm{p}^{\prime}$-DDE bioaccumulation by Cucurbita pepo (Zucchini) and Glycine max (Soybean). Environ. Sci. Technol. 2013, 47, 718-725. [CrossRef] [PubMed]

112. Lin, T.-H.; Huang, Y.-L.; Huang, S.-F. Lipid peroxidation in liver of rats administrated with methyl mercuric chloride. Biol. Trace Elem. Res. 1996, 54, 33-41. [CrossRef] [PubMed]

113. Thiruvengadam, M.; Gurunathan, S.; Chung, I.-M. Physiological, metabolic, and transcriptional effects of biologically-synthesized silver nanoparticles in turnip (Brassica rapa ssp. rapa L.). Protoplasma 2015, 252, 1031-1046. [CrossRef] [PubMed]

114. Dobias, J.; Bernier-Latmani, R. Silver release from silver nanoparticles in natural waters. Environ. Sci. Technol. 2013, 47, 4140-4146. [CrossRef] [PubMed]

115. Park, H.-J.; Kim, J.Y.; Kim, J.; Lee, J.-H.; Hahn, J.-S.; Gu, M.B.; Yoon, J. Silver-ion-mediated reactive oxygen species generation affecting bactericidal activity. Water Res. 2009, 43, 1027-1032. [CrossRef] [PubMed]

116. Tripathi, A.; Liu, S.; Singh, P.K.; Kumar, N.; Pandey, A.C.; Tripathi, D.K.; Chauhan, D.K.; Sahi, S. Differential phytotoxic responses of silver nitrate $\left(\mathrm{AgNO}_{3}\right)$ and silver nanoparticle (AgNPs) in Cucumis sativus L. Plant Gene 2017, 11, 255-264. [CrossRef]

117. Montes, A.; Bisson, M.A.; Gardella, J.A.; Aga, D.S. Uptake and transformations of engineered nanomaterials: Critical responses observed in terrestrial plants and the model plant Arabidopsis thaliana. Sci. Total Environ. 2017, 607-608, 1497-1516. [CrossRef] [PubMed]

118. Mura, S.; Greppi, G.; Irudayaraj, J. Latest developments of nanotoxicology in plants. In Nanotechnology and Plant Sciences: Nanoparticles and Their Impact on Plants; Siddiqui, M.H., Al-Whaibi, M.H., Mohammad, F., Eds.; Springer: Cham, Switzerland, 2015; pp. 125-151.

119. Chen, X.; Schluesener, H.J. Nanosilver: A nanoproduct in medical application. Toxicol. Lett. 2008, 176, 1-12. [CrossRef] [PubMed]

120. Wijnhoven, S.W.P.; Peijnenburg, W.J.G.M.; Herberts, C.A.; Hagens, W.I.; Oomen, A.G.; Heugens, E.H.W.; Roszek, B.; Bisschops, J.; Gosens, I.; Van De Meent, D.; et al. Nano-silver-A review of available data and knowledge gaps in human and environmental risk assessment. Nanotoxicology 2009, 3, 109-138. [CrossRef]

121. Anjum, N.A.; Gill, S.S.; Duarte, A.C.; Pereira, E.; Ahmad, I. Silver nanoparticles in soil-plant systems. J. Nanopart. Res. 2013, 15, 1896. [CrossRef]

122. Gross, E.L. Plastocyanin: Structure and function. Photosynth. Res. 1993, 37, 103-116. [CrossRef] [PubMed]

123. Sigfridsson, K. Plastocyanin, an electron-transfer protein. Photosynth. Res. 1998, 57, 1-28. [CrossRef]

124. Sas, K.N.; Haldrup, A.; Hemmingsen, L.; Danielsen, E.; Øgendal, L.H. pH-dependent structural change of reduced spinach plastocyanin studied by perturbed angular correlation of $\gamma$-rays and dynamic light scattering. JBIC J. Biol. Inorg. Chem. 2006, 11, 409. [CrossRef] [PubMed]

125. Sujak, A. Interaction between cadmium, zinc and silver-substituted plastocyanin and cytochrome b6f complex-Heavy metals toxicity towards photosynthetic apparatus. Acta Physiol. Plant 2005, 27, 61-69. [CrossRef]

126. Jansson, H.; Hansson, Ö. Competitive inhibition of electron donation to photosystem 1 by metal-substituted plastocyanin. Biochim. Biophys. Acta 2008, 1777, 1116-1121. [CrossRef] [PubMed]

127. Navarro, E.; Piccapietra, F.; Wagner, B.; Marconi, F.; Kaegi, R.; Odzak, N.; Sigg, L.; Behra, R. Toxicity of silver nanoparticles to Chlamydomonas reinhardtii. Environ. Sci. Technol. 2008, 42, 8959-8964. [CrossRef] [PubMed]

128. Ruotolo, R.; Maestri, E.; Pagano, L.; Marmiroli, M.; White, J.C.; Marmiroli, N. Plant response to metal-containing engineered nanomaterials: An omics-based perspective. Environ. Sci. Technol. 2018, 52, 2451-2467. [CrossRef] [PubMed]

129. Wang, P.; Lombi, E.; Zhao, F.-J.; Kopittke, P.M. Nanotechnology: A new opportunity in plant sciences. Trends Plant Sci. 2016, 21, 699-712. [CrossRef] [PubMed]

130. Rastogi, A.; Zivcak, M.; Sytar, O.; Kalaji, H.M.; He, X.; Mbarki, S.; Brestic, M. Impact of metal and metal oxide nanoparticles on plant: A critical review. Front. Chem. 2017, 5, 78. [CrossRef] [PubMed]

131. Nel, A.; Xia, T.; Mädler, L.; Li, N. Toxic potential of materials at the nanolevel. Science 2006, 311, $622-627$. [CrossRef] [PubMed] 
132. Abdel-Azeem, E.A.; Elsayed, B.A. Phytotoxicity of silver nanoparticles on Vicia faba seedlings. N. Y. Sci. J. 2013, 6, 148-156.

133. Oukarroum, A.; Barhoumi, L.; Pirastru, L.; Dewez, D. Silver nanoparticle toxicity effect on growth and cellular viability of the aquatic plant Lemna gibba. Environ. Toxicol. Chem. 2013, 32, 902-907. [CrossRef] [PubMed]

134. Levard, C.; Hotze, E.M.; Lowry, G.V.; Brown, G.E. Environmental transformations of silver nanoparticles: Impact on stability and toxicity. Environ. Sci. Technol. 2012, 46, 6900-6914. [CrossRef] [PubMed]

135. Tejamaya, M.; Römer, I.; Merrifield, R.C.; Lead, J.R. Stability of citrate, PVP, and PEG coated silver nanoparticles in ecotoxicology media. Environ. Sci. Technol. 2012, 46, 7011-7017. [CrossRef] [PubMed]

136. Rico, C.M.; Peralta-Videa, J.R.; Gardea-Torresdey, J.L. Chemistry, biochemistry of nanoparticles, and their role in antioxidant defense system in plants. In Nanotechnology and Plant Sciences: Nanoparticles and Their Impact on Plants; Siddiqui, M.H., Al-Whaibi, M.H., Mohammad, F., Eds.; Springer: Cham, Switzerland, 2015; pp. 1-17.

137. Apel, K.; Hirt, H. Reactive oxygen species: Metabolism, oxidative stress, and signal transduction. Annu. Rev. Plant Biol. 2004, 55, 373-399. [CrossRef] [PubMed]

138. Krishnaraj, C.; Jagan, E.G.; Ramachandran, R.; Abirami, S.M.; Mohan, N.; Kalaichelvan, P.T. Effect of biologically synthesized silver nanoparticles on Bacopa monnieri (Linn.) Wettst. plant growth metabolism. Process Biochem. 2012, 47, 651-658. [CrossRef]

139. Gould, K.S. Nature's Swiss army knife: The diverse protective roles of anthocyanins in leaves. Biomed Res. Int. 2004, 2004, 314-320. [CrossRef] [PubMed]

140. He, D.; Jones, A.M.; Garg, S.; Pham, A.N.; Waite, T.D. Silver nanoparticle-reactive oxygen species interactions: Application of a charging-discharging model. J. Phys. Chem. C 2011, 115, 5461-5468. [CrossRef]

141. Chew, B.P.; Park, J.S. Carotenoid action on the immune response. J. Nutr. 2004, 134, 257S-261S. [CrossRef] [PubMed]

142. Zechmann, B.; Müller, M.; Zellnig, G. Modified levels of cysteine affect glutathione metabolism in plant cells. In Sulfur Assimilation and Abiotic Stress in Plants; Khan, N.A., Singh, S., Umar, S., Eds.; Springer: Berlin/Heidelberg, Germany, 2008; pp. 193-206.

143. Tangaa, S.R.; Selck, H.; Winther-Nielsen, M.; Khan, F.R. Trophic transfer of metal-based nanoparticles in aquatic environments: A review and recommendations for future research focus. Environ. Sci. Nano 2016, 3 , 966-981. [CrossRef]

144. Kalman, J.; Paul, K.B.; Khan, F.R.; Stone, V.; Fernandes, T.F. Characterisation of bioaccumulation dynamics of three differently coated silver nanoparticles and aqueous silver in a simple freshwater food chain. Environ. Chem. 2015, 12, 662-672. [CrossRef]

145. McTeer, J.; Dean, A.P.; White, K.N.; Pittman, J.K. Bioaccumulation of silver nanoparticles into Daphnia magna from a freshwater algal diet and the impact of phosphate availability. Nanotoxicology 2014, 8, 305-316. [CrossRef] [PubMed]

146. Park, H.-G.; Kim, J.I.; Chang, K.-H.; Lee, B.-C.; Eom, I.-C.; Kim, P.; Nam, D.-H.; Yeo, M.-K. Trophic transfer of citrate, PVP coated silver nanomaterials, and silver ions in a paddy microcosm. Environ. Pollut. 2018, 235, 435-445. [CrossRef] [PubMed]

147. Judy, J.D.; Unrine, J.M.; Rao, W.; Bertsch, P.M. Bioaccumulation of gold nanomaterials by Manduca sexta through dietary uptake of surface contaminated plant tissue. Environ. Sci. Technol. 2012, 46, 12672-12678. [CrossRef] [PubMed]

148. Hawthorne, J.; De la Torre Roche, R.; Xing, B.; Newman, L.A.; Ma, X.; Majumdar, S.; Gardea-Torresdey, J.; White, J.C. Particle-size dependent accumulation and trophic transfer of cerium oxide through a terrestrial food chain. Environ. Sci. Technol. 2014, 48, 13102-13109. [CrossRef] [PubMed]

149. De la Torre Roche, R.; Servin, A.; Hawthorne, J.; Xing, B.; Newman, L.A.; Ma, X.; Chen, G.; White, J.C. Terrestrial trophic transfer of bulk and nanoparticle $\mathrm{La}_{2} \mathrm{O}_{3}$ does not depend on particle size. Environ. Sci. Technol. 2015, 49, 11866-11874. [CrossRef] [PubMed]

150. Sung, J.H.; Ji, J.H.; Yoon, J.U.; Kim, D.S.; Song, M.Y.; Jeong, J.; Han, B.S.; Han, J.H.; Chung, Y.H.; Kim, J.; et al. Lung function changes in Sprague-Dawley rats after prolonged inhalation exposure to silver nanoparticles. Inhal. Toxicol. 2008, 20, 567-574. [CrossRef] [PubMed] 
151. Kim, Y.S.; Kim, J.S.; Cho, H.S.; Rha, D.S.; Kim, J.M.; Park, J.D.; Choi, B.S.; Lim, R.; Chang, H.K.; Chung, Y.H.; et al. Twenty-eight-day oral toxicity, genotoxicity, and gender-related tissue distribution of silver nanoparticles in Sprague-Dawley rats. Inhal. Toxicol. 2008, 20, 575-583. [CrossRef] [PubMed]

152. Luo, Y.-H.; Chang, L.W.; Lin, P. Metal-based nanoparticles and the immune system: Activation, inflammation, and potential applications. Biomed Res. Int. 2015, 2015, 143720. [CrossRef] [PubMed]

153. Jang, J.; Lim, D.-H.; Choi, I.-H. The impact of nanomaterials in immune system. Immune Netw. 2010, 10, 85-91. [CrossRef] [PubMed]

154. Arora, S.; Jain, J.; Rajwade, J.M.; Paknikar, K.M. Cellular responses induced by silver nanoparticles: In vitro studies. Toxicol. Lett. 2008, 179, 93-100. [CrossRef] [PubMed]

(C) 2019 by the authors. Licensee MDPI, Basel, Switzerland. This article is an open access article distributed under the terms and conditions of the Creative Commons Attribution (CC BY) license (http:/ / creativecommons.org/licenses/by/4.0/). 